ENVIRONMENTAL RESTORATION PROGRAM

\section{Site Characterization Summary Report for the Old Hydrofracture Facility, Waste Area Grouping 5, at Oak Ridge National Laboratory, Oak Ridge, Tennessee}

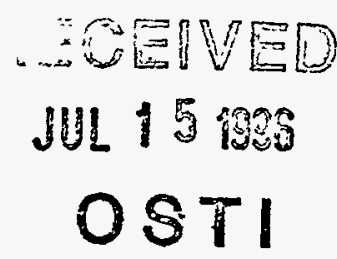

This document has been approved by the ORNL Technical Information Office for release to the public. Date: $4 / 1 / 96$ 
Advanced Integrated Management Services, Inc. and CDM Federal Programs Corporation

contributed to the preparation of this document and should not be considered an eligible contractor for its review.

This report has been reproduced directly from the best available copy.

Available to DOE and DOE contractors from the Office of Scientific and Technical Information, P.O. Box 62, Oak Ridge, TN 37831; prices available from 423-576-8401 (fax 423-576-2865).

Available to the public from the National Technical Information Service, U.S. Department of Commerce, 5285 Port Royal Rd., Springfield, VA 22161. 
Energy Systems Environmental Restoration Program

\section{Site Characterization Summary Report \\ for the Old Hydrofracture Facility, Waste Area Grouping 5, \\ at Oak Ridge National Laboratory, Oak Ridge, Tennessee}

Date Issued-April 1996

Prepared by

Advanced Integrated Management Services, Inc. and CDM Federal Programs Corporation

Oak Ridge, Tennessee

under subcontract 7908011CTP0

Prepared for the

U.S. Department of Energy

Office of Environmental Management under budget and reporting code EW 20

Environmental Management Activities at the OAK RIDGE NATIONAL LABORATORY

Oak Ridge, Tennessee 37831-6285

managed by

LOCKHEED MARTIN ENERGY SYSTEMS, INC.

for the

U.S. DEPARTMENT OF ENERGY

under contract DE-AC05-84OR21400 


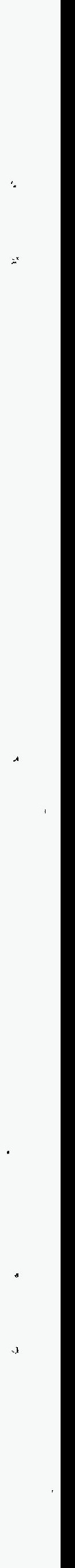




\section{PREFACE}

This site characterization summary report summarizes the operational history and other information on the Old Hydrofracture Facility located in Waste Area Grouping 5 at the Oak Ridge National Laboratory, Oak Ridge, Tennessee. The Old Hydrofracture Facility was a waste disposal facility that operated from the 1960 s until 1979. Intermediate-level liquid waste was mixed with grout and injected deep underground for permanent disposal. Facilities at the site include various buildings, pipes, waste pits, and five underground storage tanks that contain liquid and sludge that have been characterized as low-level, hazardous, and mixed waste.

\section{DISCLAIMER}

This report was prepared as an account of work sponsored by an agency of the United States Government. Neither the United States Government nor any agency thereof, nor any of their employees, makes any warranty, express or implied, or assumes any legal liability or responsibility for the accuracy, completeness, or usefulness of any information, apparatus, product, or process disclosed, or represents that its use would not infringe privately owned rights. Reference herein to any specific commercial product, process, or service by trade name, trademark, manufacturer, or otherwise does not necessarily constitute or imply its endorsement, recommendation, or favoring by the United States Government or any agency thereof. The views and opinions of authors expressed herein do not necessarily state or reflect those of the United States Government or any agency thereof. 



\section{CONTENTS}

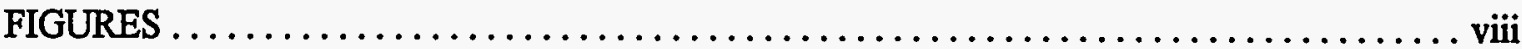

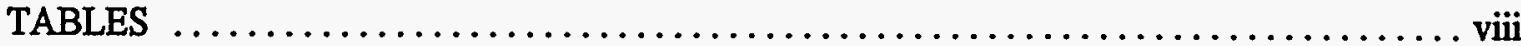

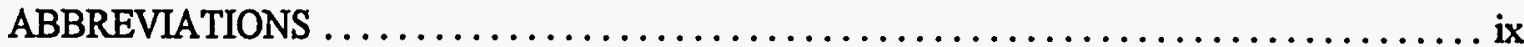

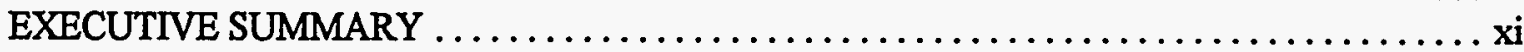

1. INTRODUCTION AND FACILITY BACKGROUND $\ldots \ldots \ldots \ldots \ldots \ldots \ldots \ldots \ldots .1$

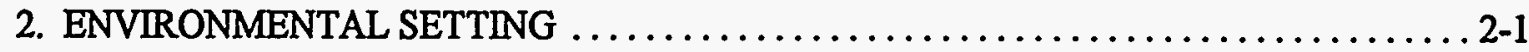

2.1 SURROUNDING POPULATION $\ldots \ldots \ldots \ldots \ldots \ldots \ldots \ldots \ldots \ldots \ldots \ldots \ldots \ldots \ldots \ldots \ldots, 2-1$

2.2 LAND USE $\ldots \ldots \ldots \ldots \ldots \ldots \ldots \ldots \ldots \ldots \ldots \ldots \ldots \ldots \ldots \ldots \ldots \ldots \ldots \ldots \ldots \ldots \ldots \ldots, 1$

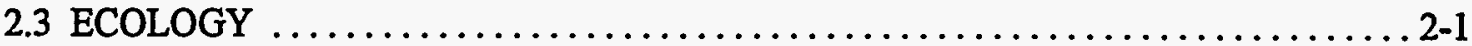

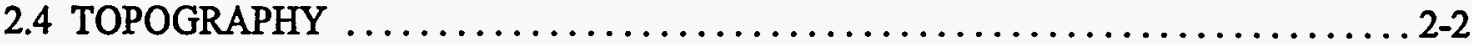

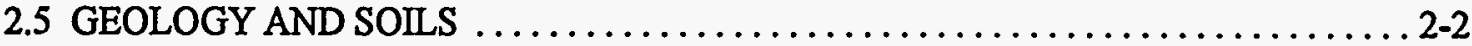

2.5.1 Bedrock Geology . . . . . . . . . . . . . . . . . . . . . . . . . . . . . . . . 2-2

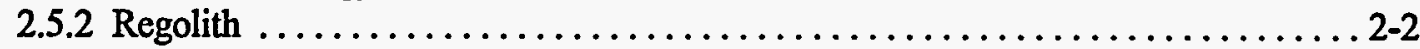

2.6 HYDROLOGY $\ldots \ldots \ldots \ldots \ldots \ldots \ldots \ldots \ldots \ldots \ldots \ldots \ldots \ldots \ldots \ldots \ldots \ldots \ldots \ldots \ldots, 2$

2.7 CLIMATE $\ldots \ldots \ldots \ldots \ldots \ldots \ldots \ldots \ldots \ldots \ldots \ldots \ldots \ldots \ldots \ldots \ldots \ldots \ldots \ldots \ldots \ldots, 2-6$

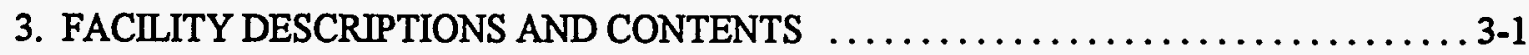

3.1 BUILDINGS AND MISCELLANEOUS STRUCTURES $\ldots \ldots \ldots \ldots \ldots \ldots \ldots \ldots .1$

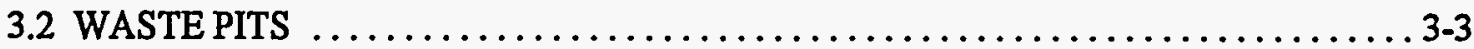

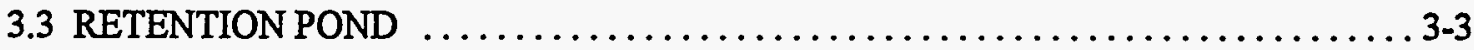

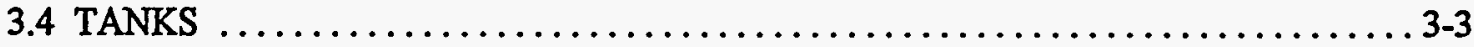

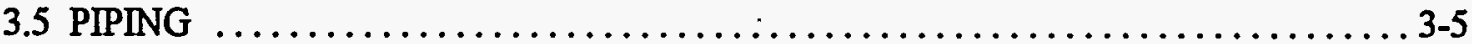

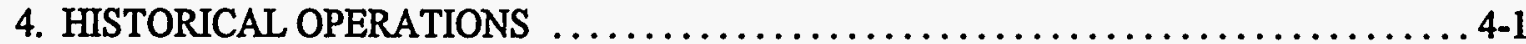

4.1 OHF FACILITY OPERATIONS 1964 TO $1980 \ldots \ldots \ldots \ldots \ldots \ldots \ldots \ldots \ldots$. $\ldots \ldots \ldots$

4.2 OPERATING OCCURRENCES OF INTEREST $\ldots \ldots \ldots \ldots \ldots \ldots \ldots \ldots \ldots \ldots, 4-5$

5. CURRENT SURVEILLANCE AND MAINTENANCE ACTIVITIES $\ldots \ldots \ldots \ldots \ldots . .5-1$

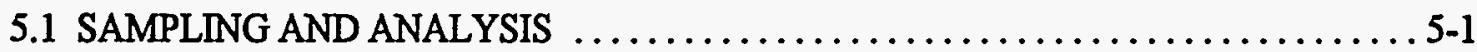

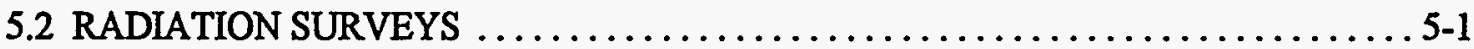

5.3 SYSTEM OPERATIONAL AND INTEGRITY TESTS $\ldots \ldots \ldots \ldots \ldots \ldots \ldots \ldots .5, \ldots \ldots \ldots$

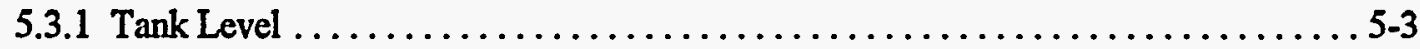

5.3 .2 Integrity Tests $\ldots \ldots \ldots \ldots \ldots \ldots \ldots \ldots \ldots \ldots \ldots \ldots \ldots \ldots \ldots, 5,4$

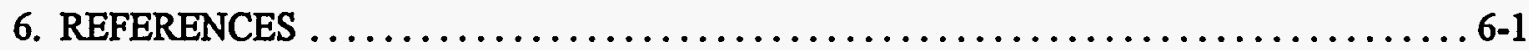

APPENDIX A - SUMMARY OF TANK INFORMATION $\ldots \ldots \ldots \ldots \ldots \ldots \ldots \ldots$ A-1

APPENDIX B - SELECTED SAMPLING RESULTS FROM $1988 \ldots \ldots \ldots \ldots \ldots \ldots \ldots$. B-1 


\section{FIGURES}

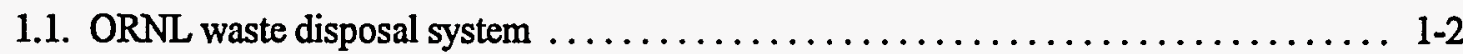

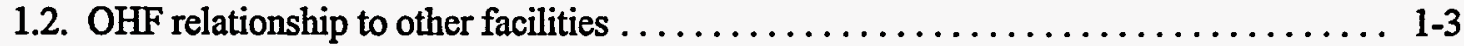

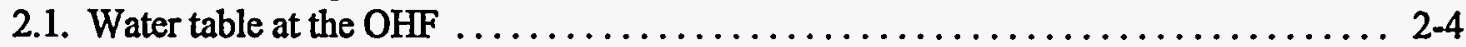

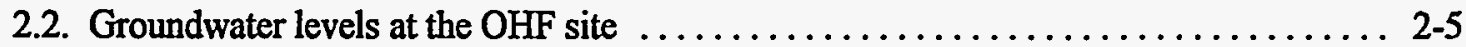

3.1. OHF site layout $\ldots \ldots \ldots \ldots \ldots \ldots \ldots \ldots \ldots \ldots \ldots \ldots \ldots \ldots \ldots \ldots \ldots \ldots \ldots \ldots \ldots \ldots \ldots \ldots, 2$

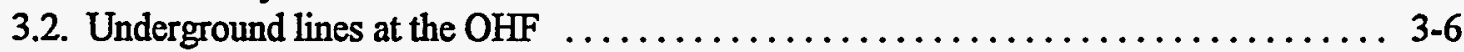

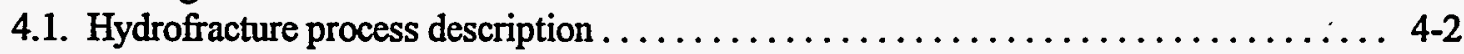

\section{TABLES}

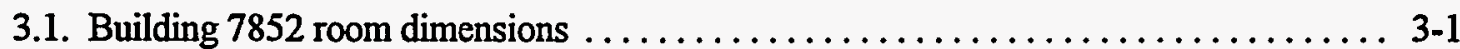

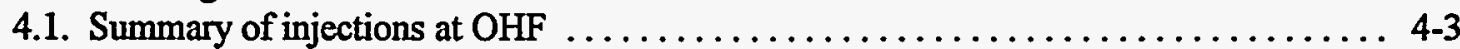

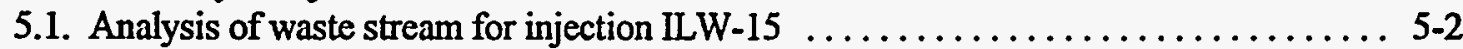

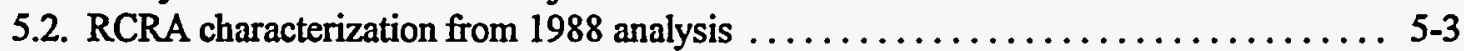




\section{ABBREVIATIONS}

$\begin{array}{ll}\text { amsl } & \text { above mean sea level } \\ \text { DOE } & \text { U.S. Department of Energy } \\ \text { EP } & \begin{array}{l}\text { extraction procedure } \\ \text { facility manager }\end{array} \\ \text { FM } & \text { Hydrologic Simulation Program-FORTRAN } \\ \text { HSPF } & \text { intermediate liquid low-level waste } \\ \text { ILLLW } & \text { intermediate-level waste } \\ \text { ILW } & \text { Melton Valley Storage Tanks } \\ \text { MVST } & \text { Old Hydrofracture } \\ \text { OHF } & \text { Oak Ridge National Laboratory } \\ \text { ORNL } & \text { Oak Ridge Reservation } \\ \text { ORR } & \text { Resource Conservation and Recovery Act } \\ \text { RCRA } & \text { Solid Waste Storage Area } \\ \text { SWSA } & \text { transuranic } \\ \text { TRU } & \text { Ultrasonic Ranging and Data System } \\ \text { USRADS } & \text { underground storage tank } \\ \text { UST } & \text { waste acceptance criteria } \\ \text { WAC } & \text { Waste Area Grouping } \\ \text { WAG } & \text { White Oak Creek } \\ \text { WOC } & \end{array}$




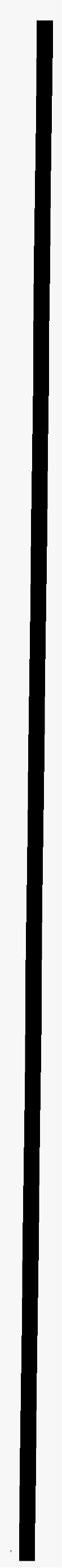




\section{EXECUTIVE SUMMARY}

The Old Hydrofracture (OHF) Facility was an experimental waste disposal test site located at the Oak Ridge National Laboratory (ORNL) in Oak Ridge, Tennessee. The ORNL is a research facility owned by the U.S. Department of Energy (DOE) and managed by Lockheed Martin Energy Research Corp. Legacy environmental restoration sites, such as the OHF Facility, are managed for DOE by Lockheed Martin Energy Systems, Inc.

The OHF Facility consists of five underground storage tanks (classified as Category D tanks in the Federal Facilities Agreement), several buildings, various piping, a retention pond, and waste pits. Intermediate-level liquid radioactively contaminated wastes from ORNL operations were piped to the OHF Facility, blended with grout, and injected into underground shale strata for permanent disposal. Operations at the OHF Facility began in 1963, when the facility was constructed, and continued until 1980 , when all waste injections were terminated. Since that time, only surveillance and maintenance activities have been performed at the facility.

The five tanks at the facility functioned as temporary storage for the liquid waste before blending and injection. When operations ceased, sludge remained in the tanks. Since then, additional liquids from the retention pond and waste pits have been added to the tanks. Approximately 42,000 gal of liquid and sludge are present in the tanks. Sampling data indicate that the primary contaminants of the sludge and liquid are radioactive materials and Resource Conservation and Recovery Act metals. The curie inventory of the material in the tanks is approximately 30,000 curies. The other structures at the facility have varying levels of radioactive contamination, all a result of the blending and injection operations. The operational status of the facility components is uncertain. Some of the facility components still function (e.g, some of the valves may still work) and are structurally intact (on the basis of recent tests). Other parts of the system have ceased functioning, and their structural integrity is uncertain. 


\section{INTRODUCTION AND FACILITY BACKGROUND}

The Old Hydrofracture (OHF) Facility was an experimental waste disposal test site located at the Oak Ridge National Laboratory (ORNL) in Oak Ridge, Tennessee. ORNL is a research facility owned by the U.S. Department of Energy (DOE) and managed by Lockheed Martin Energy Research Corp. Legacy environmental restoration sites, such as the OHF Facility, are managed for DOE by Lockheed Martin Energy Systems, Inc.

This report summarizes the known conditions at the OHF Facility located in the southwest corner of Waste Area Grouping (WAG) 5 at ORNL. The facility covers about 1 acre. The facility was used for the injection of liquid intermediate-level wastes $(\mathrm{ILW})$ into a shale formation well below ground surface as a means of permanent disposal. Wastes remaining at the site after the last series of injections can be found in buildings, waste pits, the retention pond, tanks, and piping. Characterization data collected to date are provided in this report to facilitate waste removal activities.

The appropriate construction site for the OHF Facility was selected based on geology, and the facility was built in 1963. The hydrofracture process was developed at ORNL during the period 1959-1965 for the permanent disposal of locally generated waste solutions. These solutions were generally alkaline and had a radionuclide content (predominantly ${ }^{137} \mathrm{Cs}$ ) of about $1 \mathrm{Ci} /$ gal. A suitable grout mixture of cement and other solid additives was developed to combine with the wastes to permanently fix the radionuclides in the subsurface. Test injections of the blended waste and grout were made in 1964 and 1965 to demonstrate the feasibility of the process. The waste mixture was injected into a nearly impermeable shale formation at a depth of 800 to $1100 \mathrm{ft}$, well below the level at which groundwater is encountered. Upon injection, the grout formed an approximately horizontal thin sheet several hundred feet wide. The grout set a few hours after completion of the injection, thus permanently fixing the radioactive waste in the shale formation. Following the test injections, the facility became operational for the routine disposal of concentrated ILW solutions starting in 1966. A total of about 2.3million gal of waste grout containing about 650,000 curies of radionuclides was disposed of in 18 operational injections. Improvements and modifications were made to the process and the facility throughout this series of injections, which ended in 1979.

Waste solution was pumped to the site through the existing waste transfer line. Three underground storage tanks (USTs) were installed initially, and two USTs were added later.

Figure 1.1 is a sketch of the laboratory waste handling system as it existed until about 1980. Waste solution generated at various facilities in the laboratory was collected in monitored tanks near the sources. This waste was neutralized and periodically pumped to a large waste storage tank. It was then concentrated about 20 -fold in an evaporator. The concentrated bottoms were stored in gunite Tanks W-7, W-8, W-9, and W-10, centrally located within ORNL. Periodically, the concentrated waste was pumped to the OHF USTs. A schematic of the location of the OHF Facility and its relationship to other facilities is shown in Fig 1.2. Also shown are the waste transfer lines that connect the gunite tanks to the OHF Facility. 


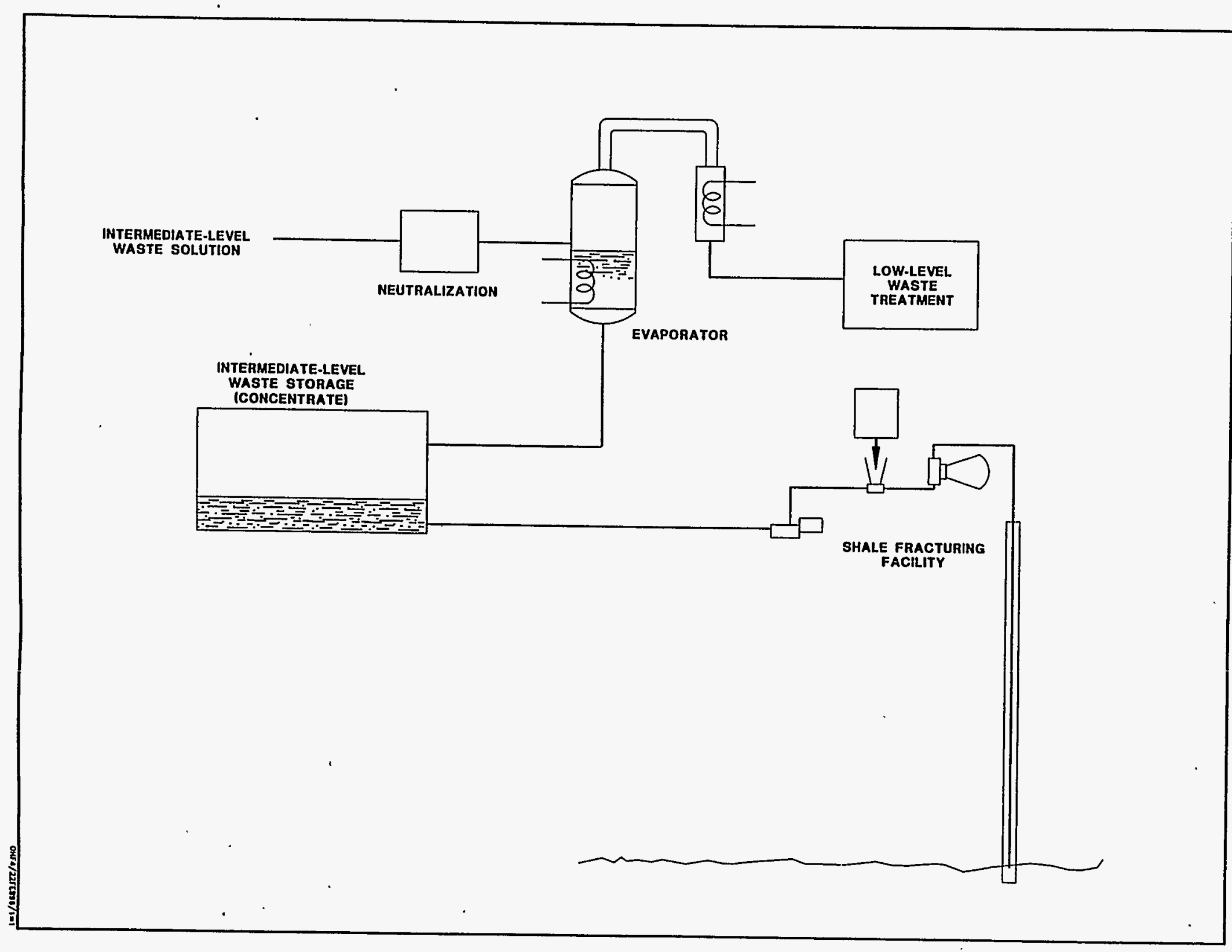

Fig. 1.1. ORNL waste disposal system. 
$1-3$

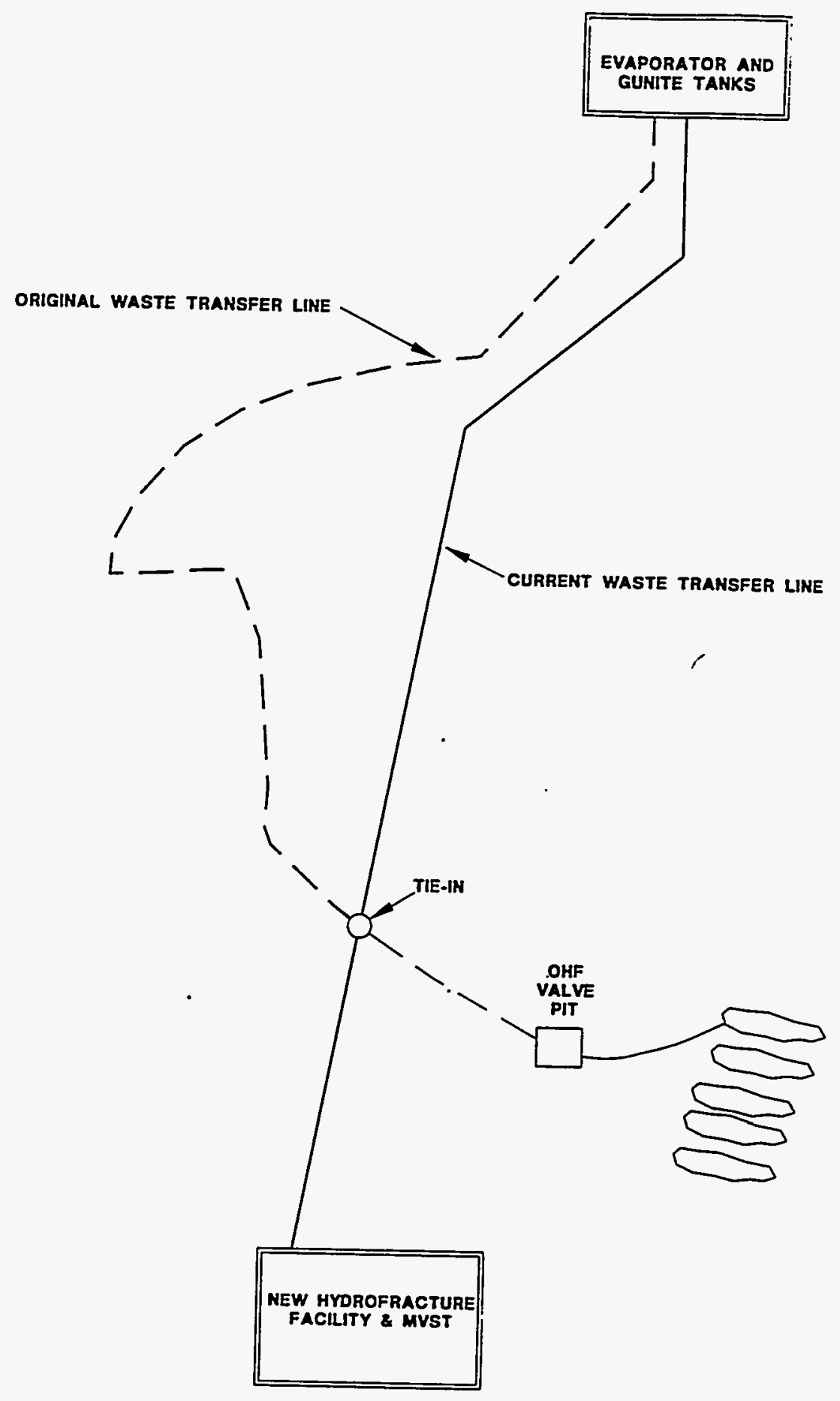

Fig. 1.2. OHF relationship to other facilities. 


\section{ENVIRONMENTAL SETTING}

Information on the environmental setting of the OHF Facility is available from many sources, and most of the data has not changed since it was initially reported. The following sections briefly summarize the information in the WAG 5 RI (DOE 1995) and the Characterization Plan for the Old Hydrofracture Facility (Francis and Stanfield 1986).

\subsection{SURROUNDING POPULATION}

Information on the surrounding population comes from the 1990 census report. The area surrounding the OHF is primarily rural, except for the city of Oak Ridge (population 27,310), 4 miles to the northeast. Oliver Springs and Kingston are small towns (population $<10,000$ each) within a 10-mile radius of the site. The metropolitan area of Knoxville and its surrounding environment (total population $\sim 670,000$ ) is 25 miles to the east. No drinking water supplies are within the Oak Ridge Reservation (ORR) boundary. A pumping station on the north bank of Melton Hill Lake at Clinch River supplies water to the Y-12 Plant and the Oak Ridge water plant.

\subsection{LAND USE}

The city of Oak Ridge is an urban center with minimal agricultural activities. Land not owned by the federal government consists of 13,615 acres and is divided into more than 9,500 parcels. Most of the urban land is either residential or undeveloped, with more than 4700 acres of the undeveloped land suitable for housing.

The OHF Facility is located within the restricted area of the ORR. Downstream of the ORR, the Clinch River and Tennessee River join within the embayment of Watts Bar Reservoir. Both the Clinch River and Watts Bar support fishing, swimming, water skiing, boating, and waterfowl hunting. Sport fishing for game fish (including striped bass, largemouth bass, crappie, and other species) constitutes a major use of the reservoir. The recreational uses of the reservoir have a significant economic impact on the communities from the marinas, bait shops, convenience stores, boat dealers, repair services, and other such services.

\subsection{ECOLOGY}

Ecological information comes from the wetlands delineation and preliminary ecological survey performed in Spring 1992. An ecological risk assessment was conducted to determine the impact of siterelated contamination on selected biological receptors and the ecosystem as a whole.

The environs surrounding the ORR are typical of the ecological systems of the Appalachian region. The OHF Facility is located in Melton Valley; dominant plant communities within this valley include grassy fields, deciduous forest, and wetlands. Developed areas around the site are associated with waste management and environmental restoration activities.

Field surveys for rare plant species in Melton Valley were conducted, and no rare species were found. No threatened or endangered bird or mammal species and no critical habitats are known to be present on the ORR; and, therefore, none should be present at the OHF site. 


\subsection{TOPOGRAPHY}

ORNL lies in the Valley and Ridge Physiographic Province. In Tennessee, the province consists of northeast-southwest striking rock strata of limestone, sandstone, and shale. The strata extend from the Virginia border on the north to the Georgia-Alabama border on the south. The strata are tilted to angles of $30^{\circ}$ and greater throughout their length, resulting in the erosion-resistant beds forming parallel ridges and those less-resistant beds becoming intervening valley floors.

\subsection{GEOLOGY AND SOILS}

The geology and soils of WAG 5 are key components to interpreting the current distribution of contamination and developing viable predictions regarding potential contaminant migration.

\subsubsection{Bedrock Geology}

WAG 5 is located in Melton Valley, approximately 1.2 miles south of ORNL. Geologically, WAG 5 is within the Copper Creek thrust block and is underlain by strata of the middle to late Cambrian Conasauga Group. The Conasauga Group in Melton Valley is approximately $1800 \mathrm{ft}$ thick and is lithologically very heterogeneous, consisting of alternating siltstones, silty limestones, calcareous shales, and mudstones.

Studies on the ORNL reservation show that the direction of groundwater movement in the bedrock is greatly affected by the directional permeability of the strata. Therefore, the overall groundwater movement would follow irregular pathways along joints and bedding planes because the bedrock strata have very low primary permeability.

\subsubsection{Regolith}

The zone between the surface and the bedrock is mostly composed of silty soil and saprolite, which is weathered or decomposed bedrock. The transition between soil and saprolite is sharp, as is the transition between saprolite and bedrock. Regolith thickness varies from a few feet at the southern boundary near Melton Branch to $40 \mathrm{ft}$ in the interior and higher topographic locations. The soil is generally $1-6 \mathrm{ft}$ deep, while the saprolite runs into the tens of feet. Much of the regolith in this area has a significant fill component consisting of locally derived and imported soils and saprolite.

\subsection{HYDROLOGY}

WAG 5 is in the Melton Valley subbasin of the White Oak Creek (WOC) drainage basin. Runoff from WAG 5 directly enters WOC and Melton Branch, as well as two unnamed tributaries of these streams. WOC flows to the south and roughly parallel to the western border of WAG 5, ranging from 100 to $300 \mathrm{ft}$ of the border; Melton Branch is within 100-300 ft of the southeastern border of WAG 5 . The two unnamed tributaries flow along the northwestern boundary and southeastern corner of WAG 5. Runoff on the southern portion of Solid Waste Storage Area (SWSA) 5 is collected in a system of concrete diversion ditches and discharge to (1) a draw (an ephemeral stream) that divides the southern portion of SWSA 5, (2) the unnamed tributary northeast of SWSA 5, and (3) the Melton Branch floodplain. Although part of the surface drainage enters Melton Branch via the draw, most of the surface drainage from the southern part of the site reaches WOC and Melton Branch via many small rivulets and dispersed pathways. The majority of the runoff from the northern portion of SWSA 5 reaches WOC via 
the draw that separates the site into its northern and southern sections. The remainder of the runoff is carried to WOC and Melton Branch by the two unnamed tributaries.

Depth to the water table at WAG 5 ranges from less than $1 \mathrm{ft}$ to more than $40 \mathrm{ft}$. Shallow water tables are typically associated with drainages and the floodplains of WOC and Melton Branch; maximum depth to water is at the topographically highest areas. The water table is typically highest between February and April (high base conditions) and lowest between August and October (low base conditions). Steeper gradients are present where topographic slopes are also steep, as expected, given the relationship between water table surface and topography. The average horizontal hydraulic gradients observed in 1993 were 0.07 during wet seasonal conditions and 0.06 during dry conditions. As Fig. 2.1 shows, the water table varies from approximately $767 \mathrm{ft}$ above mean sea level (amsl) in the northern portions of the $\mathrm{OHF}$ area to about $753 \mathrm{ft}$ amsl in the south. The gravel bed around the tanks forms a passive drainage system creating a localized change in hydrology.

Two principal WAG 5 drainages transport surface water from the site: D-1 extends from the WAG interior to WOC, and D-2 empties into Melton Branch. Drainage D-3 is a small side tributary along the east-central WAG perimeter that discharges into a larger tributary of Melton Branch. The OHF pond, constructed in 1964, measures 20 by $100 \mathrm{ft}$ and has a maximum depth of $6 \mathrm{ft}$ and a storage capacity of $100,000 \mathrm{gal}$ with sides sloping at 1 vertical on 1.5 horizontal. The pond is directly connected to shallow groundwater and therefore has a significant, if localized, impact on the water table configuration and shallow groundwater flow. Trenches around the OHF Facility impoundment direct water away from it. Buried pipelines provide for preferential flow paths, consisting of medium to highly disturbed flow.

The hydrologic model for WAG 5 is based on an integration of precipitation, surface water, groundwater, and trench hydrologic data. This model shows that the surface water is the primary integrator of hydrologic fluxes from WAG 5. Most of the precipitation that is not lost to evapotranspiration eventually makes its way to White Oak Creek. The water balance components derived from the Hydrologic Simulation Program-FORTRAN (HSPF) simulation (calibrated using flow data from D-1, D-2, and D-3) include an average annual precipitation of $53.9 \mathrm{in}$. From this amount, an average 26.1 in. is lost to evapotranspiration, and 4.8 in. becomes runoff. The remaining 23 in. infiltrates the soil, and about $38 \%$ of this ( $8.3 \mathrm{in}$.) is removed via stormflow, while the remainder (14.7 in.) percolates through the vadose zone and recharges the shallow groundwater.

The HSPF model assumed that all of the water entering the subsurface at WAG 5 is eventually discharged to Melton Branch or WOC. Figure 2.2 shows how the groundwater divides at the southwest corner of WAG 5 and the drainage from the OHF tanks goes to Melton Branch. Although the OHF impoundment is very close to the OHF tanks, the drainage from the OHF impoundment goes to WOC. Intermediate and deeper groundwater zones may have some recharging, but the total flux of water recharging these deeper zones is small [estimated to be $<1 \mathrm{~cm} /$ year]. 


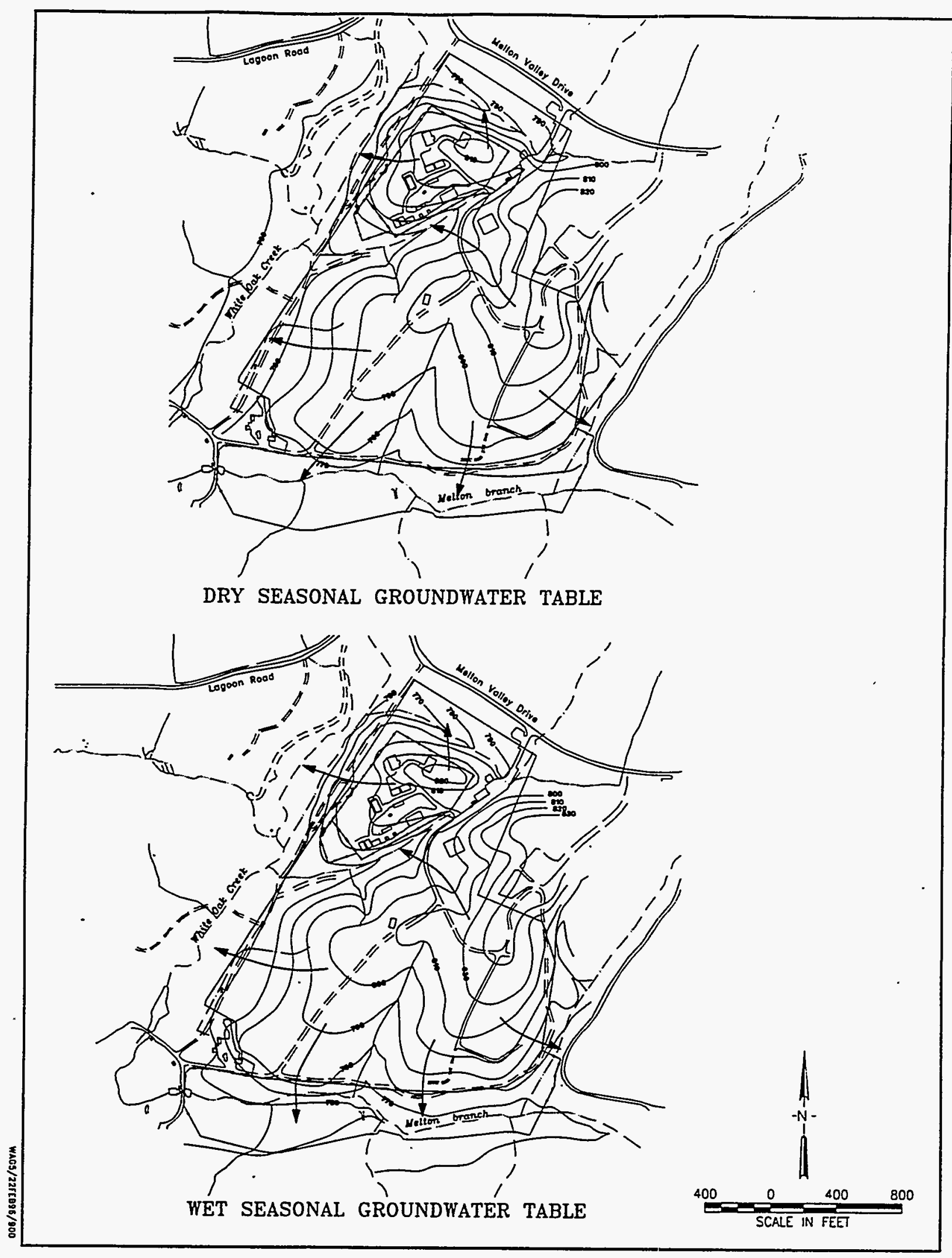

Fig. 2.1. Water table at the OHF. 


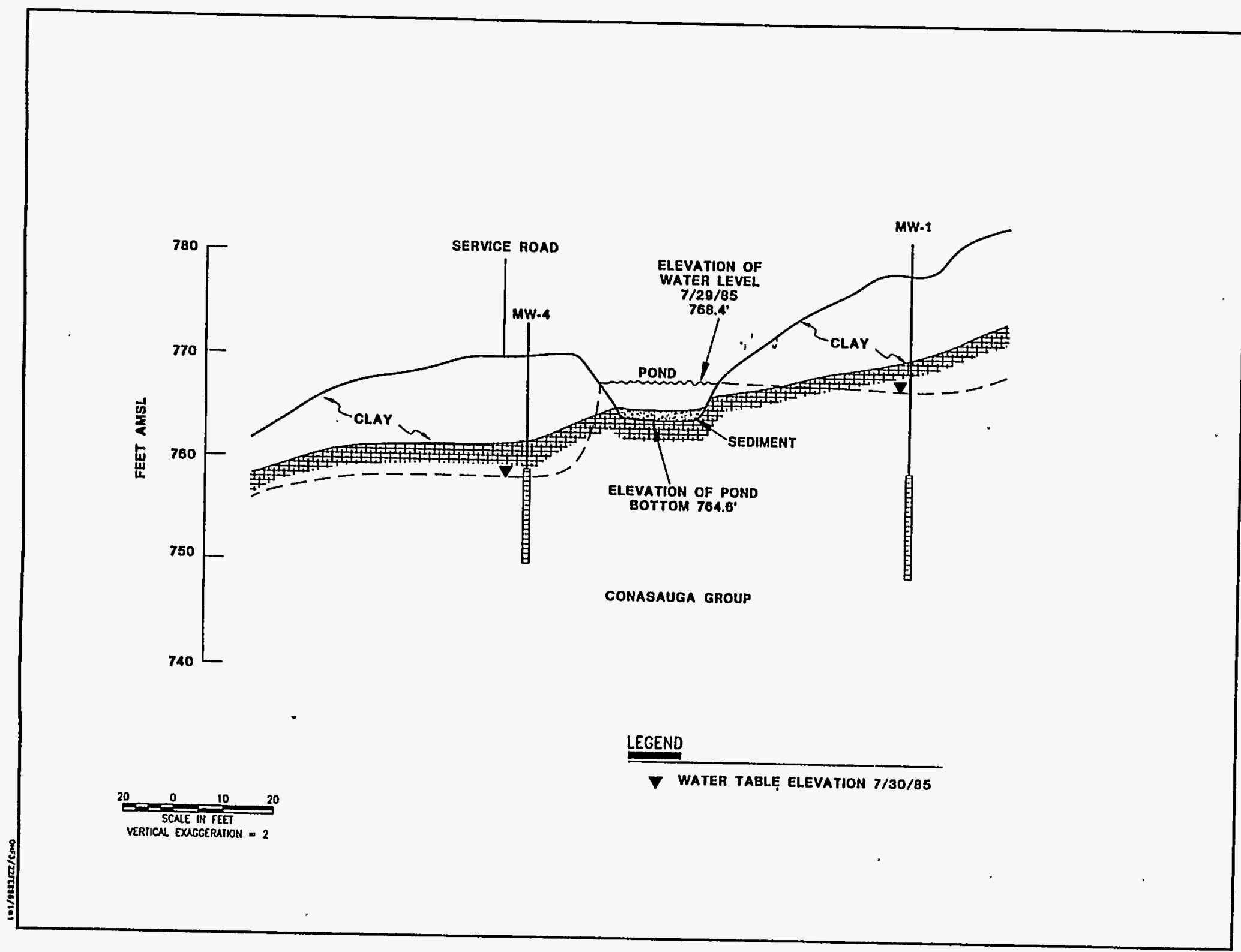

Fig. 2.2. Groundwater levels at the OHF site. 


\subsection{CLIMATE}

The Oak Ridge area has a climate with warm, humid summers and mild, wet winters. The climate is moderated by the Blue Ridge Mountains to the east and the Cumberland Plateau to the west. Weather patterns in Oak Ridge are generally temperate, with warm, humid summers and cool winters. The annual mean temperature is about $15^{\circ} \mathrm{C}\left(58^{\circ} \mathrm{F}\right)$, with a January mean of about $3.5^{\circ} \mathrm{C}\left(38^{\circ} \mathrm{F}\right)$ and a July mean of about $25^{\circ} \mathrm{C}\left(77^{\circ} \mathrm{F}\right)$. Relative humidity in mid-afternoon averages about $55 \%$. At night humidity is higher, averaging $85 \%$ at dawn.

The 30-year mean annual precipitation for the Oak Ridge area is $54.2 \mathrm{in.} \mathrm{Annual} \mathrm{rainfall} \mathrm{typically}$ ranges from 51 to $55 \mathrm{in}$ and occasionally exceeds $70 \mathrm{in}$. Winter months usually have the most rain, with another peak in July, when thunderstorms are common. Autumn is usually the season of lowest rainfall. Average annual snowfall, approximately $10 \mathrm{in}$., is not a significant contributor to precipitation.

Prevailing winds are controlled by the valley and ridge topography, which tends to direct the winds up valley (northeast) during the day and down valley (southwest) at night. According to the Atmospheric Turbulence and Diffusion Laboratory in Oak Ridge, the average wind speed for the ORR is reported to be about $4.5 \mathrm{mph}$. 


\section{FACILITY DESCRIPTIONS AND CONTENTS}

This section provides information on the facility structures and layout. Figure 3.1 displays the layout for the site and identifies the structures.

\subsection{BUILDINGS AND MISCELLANEOUS STRUCTURES}

Available information is provided for each building at the OHF site and associated structures (e.g., pipes, companion structures). Specific information on the extent of radiological contamination associated with these structures is provided when known.

Building 7852. Mixing, pumping, and injecting of grout took place in Building 7852. The mixing equipment, head-end of the injection pump and the injection wellhead were installed in cells made of 12in. concrete blocks on a concrete pad. The mixer cell and the wellhead cell were roofed with steel grating with a sheet metal cover. In 1974, shielding was added to the roof of the mixer cell to reduce the dose rate from 1 to $2 \mathrm{R} /$ hour to about one-tenth this value. Table 3.1 provides the dimensions for rooms in Building 7852.

Table 3.1. Building 7852 room dimensions

\begin{tabular}{lccc}
\hline \multicolumn{1}{c}{ Room } & $\begin{array}{c}\text { Length } \\
(\mathbf{m})\end{array}$ & $\begin{array}{c}\text { Width } \\
(\mathbf{m})\end{array}$ & $\begin{array}{c}\text { Height } \\
(\mathbf{m})\end{array}$ \\
\hline Mixing cell & 3.8 & 3.5 & 2.4 \\
Pump cell & 3 & 2.3 & 2.4 \\
Well cell & 3.3 & 3.4 & 3 \\
Control room & 4.4 & 3.3 & 3.1 \\
Engine pad & 9.1 & 3 & $2.7-3.0$ \\
\hline
\end{tabular}

Building 7853. Building 7853 was used primarily as a change room for operators.

Pump House. The pump house covers $225 \mathrm{ft}^{2}$ and is partially underground with only the roof and the southeast corner fully exposed. Two large $30-\mathrm{hp}$, progressive cavity-type Moyno pumps, used for transferring liquid from the OHF tanks to Building 7852, remain in the pump house. These pumps were obtained from Y-12 Plant surplus and frequently broke down during operations. Their current operational status is unknown.

The waste transfer line is connected to a manifold in a valve pit adjacent to the southwest corner of the pump house. From here the waste solution could be transferred to any of the waste storage tanks. The valve pit was below grade and was roofed with steel grating covered with lead shielding to reduce the operator's exposure. Extension handles ran through the pit roof to the valves. Cheater bars were used regularly because the valves were frequently difficult to turn. (The valve to T-3 was broken in the early 1980s.) One of the suction lines has a temporary patch. The valve pit is contaminated with radioactive materials. 


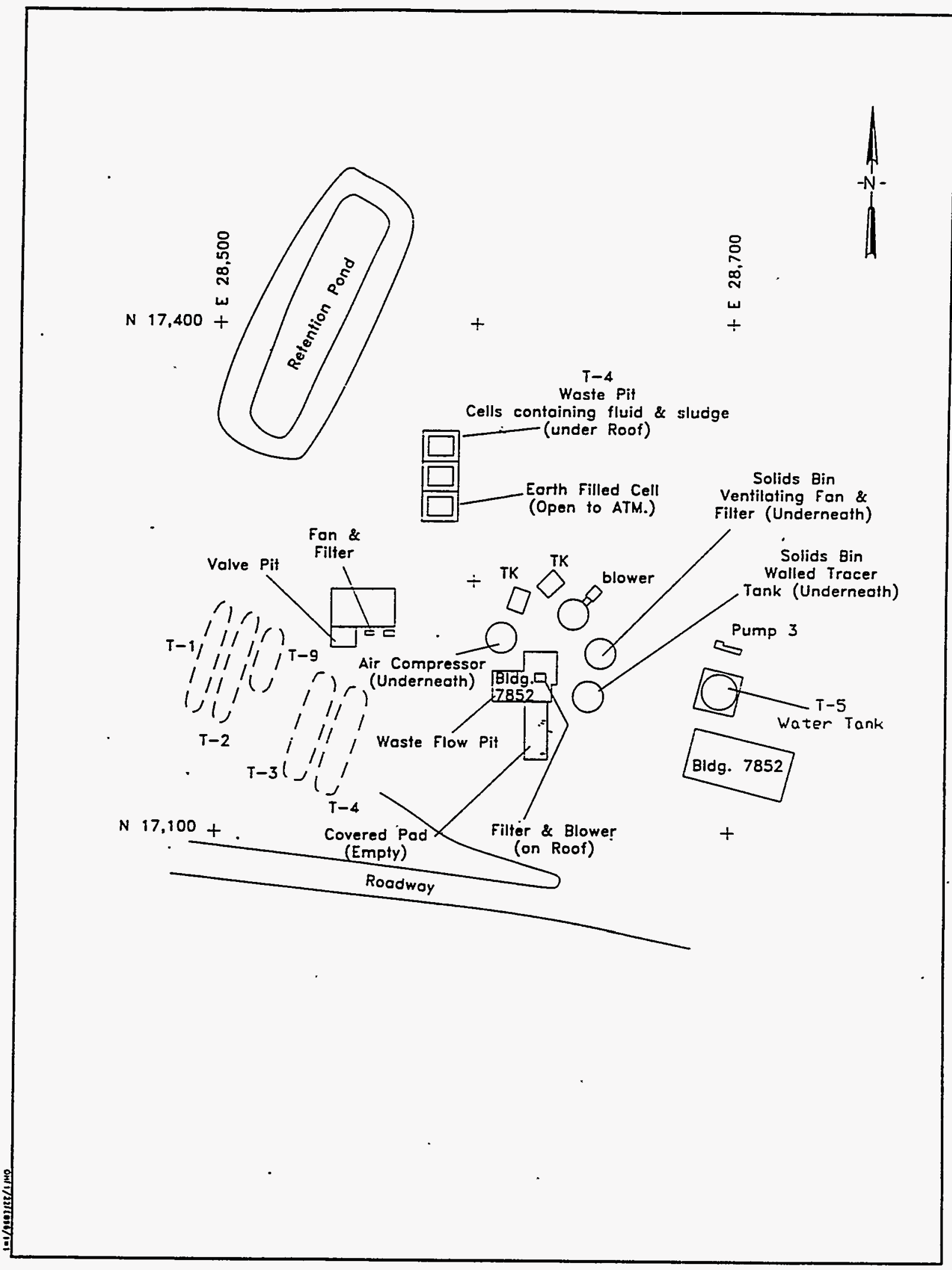

Fig. 3.1. OHF site layout. 
The pumps and piping were designed to pull waste solution from the OHF tanks and discharge to the mixer. One pump was originally intended as a spare, but in practice both pumps were operated at a reduced rate. The pump control was mounted on the operating platform adjacent to the mixer cell.

Storage Silos. Four storage silos that held the solids before mixing surround Building $\mathbf{7 8 5 2}$. Available documentation did not reveal the current contents of the silos. They may contain pellets from the final test injections or some other material. The Halliburton diesel pump used for the injections is no longer at the OHF site. On the far eastern end of the facility is a water tank with a pump to provide water slotting and cleanup of the injection well.

\subsection{WASTE PITS}

Three partially buried waste pits are at the site. The pits measure 14 by $14 \mathrm{ft}$ and are $9 \mathrm{ft}$ deep. The southernmost pit, the first one built, was filled with contaminated grout after one of the experimental injections. The other two pits were covered while the facility was in use, but now all three are open to the atmosphere.

Water and sand from the slotting and washup operation were collected in the pits. Drains from the buildings also emptied here. After the annular space in the well was flushed following a run, the water used was discharged to the waste pit. This contaminated water was later pumped back into the storage tanks. Also, rainwater that accumulated in the pits after operations at the OHF Facility had ceased was pumped into the tanks.

\subsection{RETENTION POND}

The retention pond is located to the west of the waste pits. This pond was installed to contain any grout that might be ejected from the injection well in case of a catastrophic failure of the wellhead (in such an event the flow could not be shut off). The pond is $5 \mathrm{ft}$ deep, measures 20 by $100 \mathrm{ft}$ on the bottom, and has a capacity of 100,000 gal. Drawings suggest that asphalt was sprayed on the exposed earth surface, but that was not confirmed in interviews of site personnel. No trace of an asphalt pad is now evident. These surfaces were covered with large-size crushed rock about 1966.

Two vitrified clay pipes drain into the retention pond. The first is an 18-in. line that connects to the injection well for emergency use. Only traces of radioactivity got into this line. The other line is for collecting overflows from the waste pits. Radioactive grout went into the pond in 1965 and 1977. In 1984-85 contaminated drilling fluids were put in the pond.

\subsection{TANKS}

Appendix A provides detailed information for each of the OHF USTs. The following paragraphs provide narrative descriptions. The five tanks are classified as Category D tanks in the Federal Facilities Agreement.

Tanks T-1, T-2, and T-9. Tanks T-1, T-2, and T-9 were surplus carbon steel tanks from Y-12 and were installed in 1963 at the OHF site to store ILW before injection. These tanks were refitted by ORNL shop workers and installed at the OHF site in a pit about $13 \mathrm{ft}$ deep and measuring about 36 by $48 \mathrm{ft}$ at the bottom. Some information indicated that the pits may be clay lined, but available drawings do not 
show a liner. The tanks were mounted on saddles situated on a concrete pad in a pit half filled with 1-in. gravel. A polyethylene cover was placed on top of the gravel, and the pit was filled with at least $4 \mathrm{ft}$ of earth mounded over the tops of the tanks. Concrete block walls separate T-1 from T-2 and T-2 from T-9, dividing the pit into three compartments. Dry well sumps were installed for each compartment.

Tanks T-1 and T-2 are $8 \mathrm{ft}$ in diameter and $44.1 \mathrm{ft}$ long. Nominal wall thickness is 1 in. Each tank has the capacity to store 15,000 gal. Fittings to each tank include a pneumatic level indicator, which replaced the original float-type indicator. This is installed in a 18-in. manway near the center of the tank. The tanks were also fitted with four air lift pumps, a 2-in. tank inlet nozzle near one end of the tank, and a 4-in suction line near the same end of the tank. The suction line extends from the top of the tank and into a pipe nipple at the bottom of the tank so that the residual heel will be minimized.

Tank T-9 has a diameter of $10 \mathrm{ft}$ and is $23.8 \mathrm{ft}$ long. It has a capacity of 13,000 gal. The internal piping is similar to that of T-1 and T-2 except that only two air lift pumps are installed.

Tanks T-3 and T-4. Tanks T-3 and T-4 were added to the system in 1966. They were surplus carbon steel, rubber-lined tanks and were installed in a pit next to the other three tanks. The design of the pit was very similar to that of the other pit except no concrete block wall was installed to segregate these tanks.

Each tank is $10.5 \mathrm{ft}$ in diameter and $42.1 \mathrm{ft}$ long, with 5/8-in. thick walls and a 25,000-gal capacity. Both have a rubber lining on the inside. Fittings of each tank include an 18-in. manway in the middle of each tank that contains a pneumatic level indicator, three air lift pumps, a 2-in. inlet near one end of the tank, and a 4-in. suction line near the same end. The suction line extends to near the bottom of the tank.

All five tanks are vented through high-efficiency particulate air filters that discharge to a relatively short stack at the site. A small blower provides a slight negative pressure. The off-gas capacity of this system may be limited as a result of its age and indeterminate condition.

When the hydrofracture injections were completed, all of the storage tanks were essentially empty. Material currently in the tanks comes from three sources.

1. sludge that had settled from the wastes that were stored,

2. water from the OHF waste pits, and

3. two or three loads of material from the L-6 sludge pond in burial ground 5 .

The ratio of sludge volume to liquid volume is about $10 \%$ in all tanks except $\mathrm{T}-3$, which has roughly the same amounts of sludge and liquid.

\subsection{PIPING}

Original Waste Transfer Line. Waste was originally pumped from the south tank farm in a 2-3 mile loop to the storage tanks. This line was a singly contained 2 -in. steel line for most of its length. A plastic section was replaced in 1965 or 1966 . The replacement section was reported to be stainless steel (de Laguna 1968).

The waste transfer line was pressure tested before each transfer. During transfers the pipeline was patrolled with radiation counters to provide quick warning of any leak. Sections of this pipeline have since been removed. 
Current Waste Transfer Line. When operations shifted to the New Hydrofracture Facility, a new line was created between the waste evaporator and the MVST around 1981 or 1982, a tie-in was made between the new line and the OHF line. The main purpose of the tie-in was to allow for emergency storage in the OHF tanks, but available information suggests this has never occurred.

The tie-in was accomplished by running a line from a valve box in the new line located near the OHF and connecting it to the existing carbon steel line from the OHF Facility. Plans indicate that doubly contained stainless steel was used to construct the new section of the line. About 100 to $150 \mathrm{ft}$ of the old carbon steel line was used. The condition of this line has not been determined.

Underground Lines at OHF. All of the piping to and from the tanks and all of the valves are constructed of carbon steel. A drawing of these lines is shown in Fig. 3.2. These lines are not doubly contained, the valves have corroded, and the condition of the lines is not known. Only a small section of the waste transfer line has been tested recently.

Each tank compartment has a dry well for leak detection. The dry wells are terra cotta pipes that go to the bottom of the clay pits in which the tanks sit. The pipes run horizontally through the gravel and extend up to the surface to allow for sampling. 


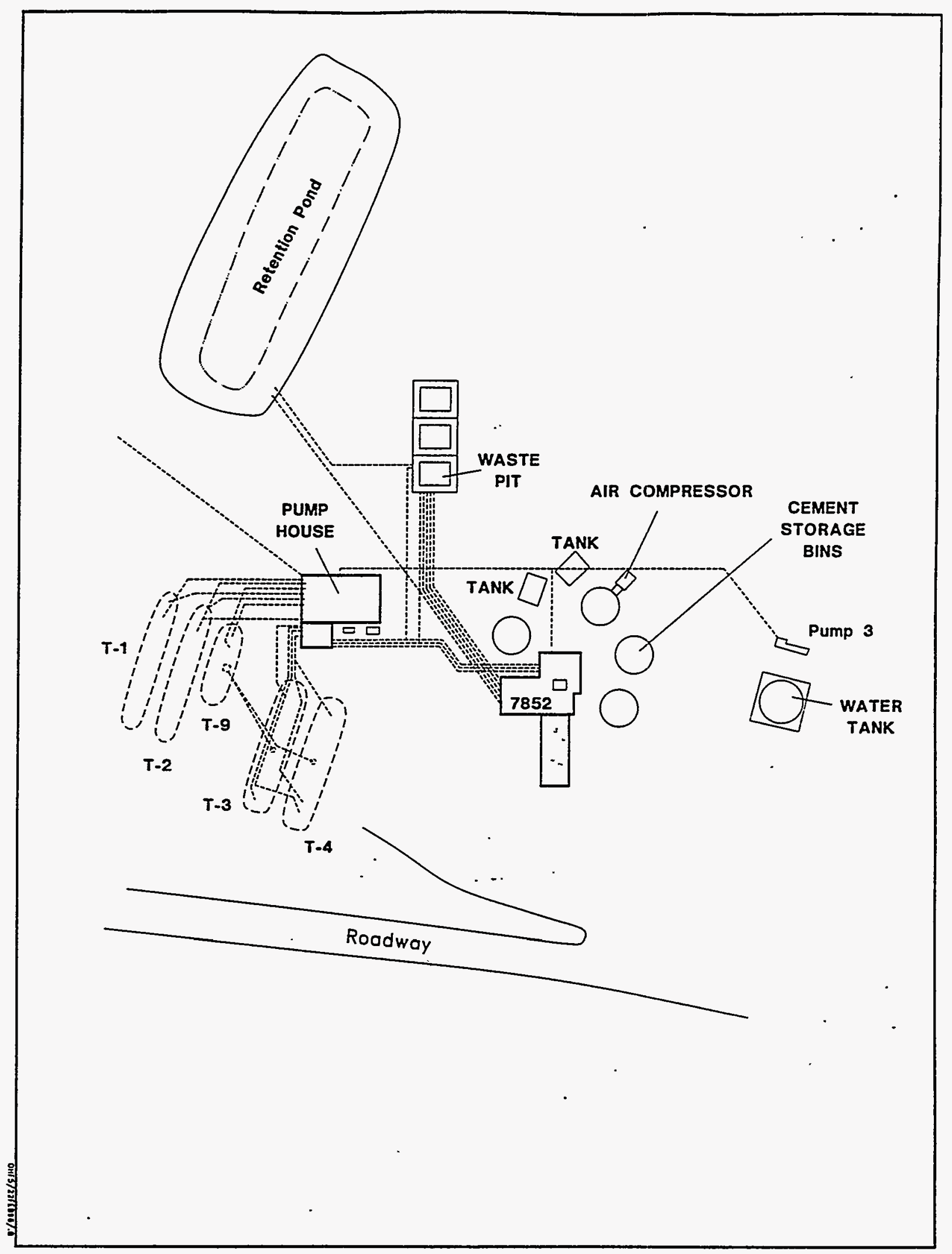

Fig. 3.2 Underground lines at the OHF. 


\section{HISTORICAL OPERATIONS}

Information on the operational history was obtained from various documents and interviews. Details on the injections appear mainly in four documents, each covering a different series of injections (de Laguna et al. 1968 and Weeren, 1974, 1976, 1980). This information was supplemented by interviews with former OHF Facility personnel.

\subsection{OHF FACILITY OPERATIONS 1964 TO 1980}

The hydrofracture process was operated as a large-scale batch process. However, each injection was a continuous operation. Each injection disposed of an annual accumulation of waste solution of about 100,000 gal. During an injection, waste solution was pumped to the mixer and mixed with a stream of dry solids. The resulting grout was pumped down the injection well and out into the shale formation at an injection pressure of about 3000 psi. A schematic of the operation is shown in Fig. 4.1.

Table 4.1 is a summary of the liquid waste injections made at the OHF Facility. The first seven injections were tests of the method and involved only waste blends with low levels of radioactivity. Two test injections of pelletized solid waste were attempted after those listed in the table.

In the later injections, it was noted that sludge was accumulating in the waste storage tanks at the hydrofracture site. This was evidenced by the loss of pump suction while an appreciable volume of waste remained in the tank. Stirring of the tank by the air lift pumps and by recirculating the tank contents temporarily alleviated the problem, but generally the loss of pump suction repeated. It is believed that small particles of insoluble materials were transferred to the hydrofracture tanks with the waste solution, settled out in the tanks, and probably agglomerated to form larger and less pumpable masses.

At least two spills occurred during the hydrofracture injections. The head blew off the injection pump on one occasion. In another instance, failure of a valve in the wellhead allowed grout to flow into the pond and waste pit.

During the last injection of actual waste (not the pellet tests) a crack occurred in a 4-in. line coming from the waste tanks to the suction side of one of the Moyno pumps. The crack was at a bell joint in the suction line about $8 \mathrm{ft}$ from the pump. The crack was repaired by using gasket material and bands. This was sufficient to permit continued operation long enough to complete the injection, but no further action was taken to repair the leak.

The normal grout injection rate was about $200 \mathrm{gal} / \mathrm{min}$, requiring about 8 to 10 hours to complete an injection operation. At the end of the injection, the well was flushed with water so that the slot would be free of grout and could be reused for the next injection. A valve then closed the well until the grout had set. Several injections were made through the same slot and formed grout sheets that were generally parallel to the first. After four injections had been made through a slot, the bottom of the well was plugged. A new slot was cut in the casing of the well $10 \mathrm{ft}$ above the old slot, and a new series of injections was made at the higher elevation. In this manner, maximum utilization of the disposal formation was achieved. 
(2) CEMENT AND OTHER SOLIDS ARE BLENDED AND STORED IN BINS

(3) WASTE IS PUMPED TO THE MIXER

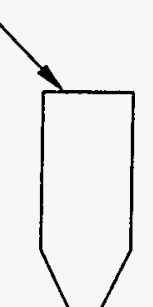

(4) SOLIDS ARE ADDED TO THE WASTE, AND THE RESULTING GROUT IS DISCHARGED TO THE MIXING TUB

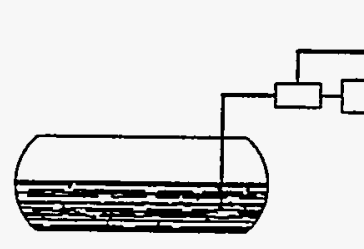

(1) WASTE SOLUTION IS STORED IN UNDERGROUND TANKS

(6) THE GROUT IS FORCED INTO THE SHALE FORMATION

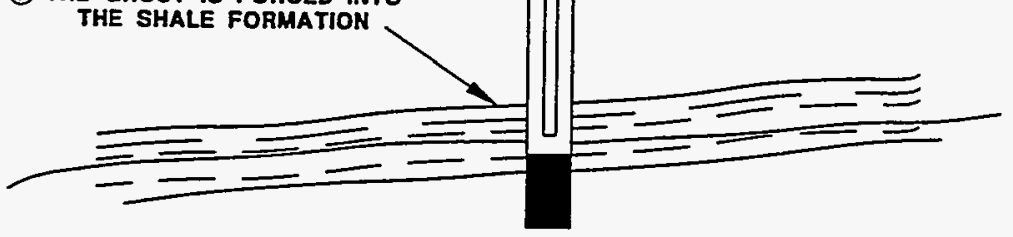

SUBSEQUENT INJECTIONS ARE MADE BY PLUGGING OLD FRACTURE AKD INITIATING A NEW FRACTURE SLIGHTLY HIGHER IN THE WELL

Fìg. 4.1. Hydrofracture process description. 
Table 4.1. Summary of injections at OHF

\begin{tabular}{|c|c|c|c|c|c|}
\hline $\begin{array}{l}\text { Injection } \\
\text { Number }\end{array}$ & Date & $\begin{array}{l}\text { Depth } \\
\text { (ft) }\end{array}$ & $\begin{array}{l}\text { Waste Vol. } \\
\text { (gal) }\end{array}$ & $\begin{array}{l}\text { Grout Vol. } \\
\text { (gal) }\end{array}$ & $\begin{array}{l}\text { Radionuclides } \\
\text { (Curies) }\end{array}$ \\
\hline 1 & Feb. 1964 & 945 & 37300 &, 40400 & - \\
\hline 2 & Feb. 1964 & 924 & 33300 & 46000 & 30 \\
\hline 3 & Apr. 1964 & 912 & 33500 & 46200 & 50 \\
\hline 4 & Apr. 1964 & 900 & 36000 & 57000 & 55 \\
\hline 5 & May 1964 & 890 & 148000 & 200000 & 150 \\
\hline 6 & May 1965 & 880 & 50400 & 70600 & 1930 \\
\hline 7 & Aug. 1965 & 872 & 97000 & 104000 & 3550 \\
\hline ILW-1 & Dec. 1966 & 872 & 62000 & 95200 & 20000 \\
\hline ILW-2 & Apr. 1967 & 862 & 148000 & 230400 & 60000 \\
\hline ILW-3 & Nov. 1967 & 862 & 83000 & 146800 & 26000 \\
\hline Water & Dec. 1967 & 852 & 44700 & - & - \\
\hline ILW-4 & Apr. 1968 & 852 & 86200 & 130700 & 56200 \\
\hline ILW-5 & Oct. 1968 & 842 & 81800 & 115000 & 70000 \\
\hline ILW-6 & June 1969 & 842 & 79400 & 126300 & 97900 \\
\hline ILW-7 & Sept. 1970 & 842 & 83000 & 145700 & 47500 \\
\hline ILW-8 & Sept. 1972 & 832 & 72700 & 108600 & 28000 \\
\hline ILW-9 & Oct. 1972 & 832 & 68300 & 114000 & 23600 \\
\hline ILW-10 & Nov. 1972 & 832 & 84800 & 133000 & 20100 \\
\hline ILW-11 & Dec. 1972 & 832 & 75800 & 125500 & 24700 \\
\hline ILW-12 & Jan. 1975 & 822 & 25700 & 42100 & 14100 \\
\hline ILW-13 & Apr. 1975 & 822 & 81000 & 126100 & 39100 \\
\hline ILW-14 & June 1975 & 822 & 83000 & 138700 & 33400 \\
\hline ILW-15 & June 1977 & 822 & 91000 & 145000 & 26500 \\
\hline ILW-16 & Nov. 1977 & 812 & 55200 & 79500 & 16500 \\
\hline ILW-17 & Sept. 1978 & 802 & 82300 & 137500 & 22400 \\
\hline ILW-18 & May 1979 & 792 & 83000 & 139000 & 16900 \\
\hline
\end{tabular}


Early in the injection program, it was found that adding small amounts of a defoamer (tributyl phosphate) to the waste stream was necessary for smooth operation of the injection pump and proper control of mix proportioning. The defoaming compound was added to the suction side of the valve manifold during each injection using a small positive displacement pump.

Before the 1975 injections, a turbine flowmeter was installed in the waste line from the pumps, in the valve pit adjacent to the pump house. A strainer with approximately a 1/8-in. mesh screen was installed upstream of this instrument. In series with the turbine flowmeter, a second orifice-type flowmeter was installed to provide a backup indication of the waste flow rate.

The dry constituents of the grouting mix were brought to the site in transporter trucks. Earlier in the injection program some mix components were procured in bags, making solids blending a very dusty operation. The trucks were unloaded in sequence into a weigh hopper and then pneumatically transferred two or more times to blend the mixture thoroughly. The mixture was then stored in the bulk storage tanks pending the next injection cycle.

The equipment in the mixer cell was designed to blend the dry solids with the waste solution in the correct proportions to produce a grout with all of the desired properties. Several modifications were made during the operational life of the facility; the following describes the final configuration.

The mixer used to blend the dry solids and the waste solution was a jet mixer, a device commonly used in the oil well cementing industry. Inside this device, the waste solution was pumped through a nozzle at the back of the unit. This provides sufficient suction to pull the dry solids out of the mixer hopper and sufficient turbulence to mix the solids and the waste to produce a fluid grout. The grout was discharged into the mixing tub that provides surge capacity between the mixer and the injection pump so that the pumps could be synchronized as much as possible. Pumping the grout into the mixing tub also allowed time for entrained air to separate from the grout. The blended grout flowed to the suction side of the injection pump, which forced it through the wellhead piping and down the injection well.

In this operation the control of the mix ratio-the pounds of dry solids used per gallon of waste solution - was crucial. The mix ratio was determined continuously during an injection by measuring the dry solids flow rate and the liquid flow rate by as many different methods as possible. The "most reasonable" of these readings was selected, and the ratio was calculated at 5-minute intervals. The liquid flow rate was measured by three different ways: orifice meter, turbine meter, and the fall in level of the waste storage tanks. Two methods of measuring the solids flow rate were employed. A mass flowmeter measured the impact of the flowing solids and the consumption of solids from the solids storage bins. A stroke counter on the injection pump measured the volume of the injected grout. All of the readings were correlated at 5-minute intervals.

At the end of an injection the equipment was washed to remove grout residues from the piping and equipment. The washing operation added to the contamination of the facility. Water for the operation came from the water storage tank at the site while the residues from the washdown were drained to the waste pit where the solids settled out. The contaminated liquid was used at the beginning or the end of the next injection to partially decontaminate the system. Sand used in the slotting operation was also collected in the waste pit. 


\subsection{OPERATING OCCURRENCES OF INTEREST}

The fifth experimental injection (May 1964) was planned as a large volume injection, larger than the capacity of the three waste storage tanks then at the site. For this injection, when each waste storage tank was pumped empty it was refilled with a nonradioactive waste solution. The additional tank agitation caused by the refilling and emptying over a short interval apparently resuspended some solids that had precipitated and settled in the tank. Analyses showed the concentrations of some less soluble radionuclides were much higher in the second emptying of the tank than during the first emptying. For instance, 285 curies of ${ }^{144} \mathrm{Ce}$ were in the first emptying of the tanks, 3550 curies in the second emptying, and 264 curies in the third emptying. These types of mechanics, settling of fine particles and incomplete resuspension, are probably responsible for the buildup of the current inventory of radionuclides in the OHF Facility waste storage tanks.

Before experimental injection 6 (May 1965), the viewing window for the mixer hopper was eliminated. It was thought that the new mass meter flow device would provide sufficient information and that vision into the hopper was no longer needed. Also, the cementer, who was stationed immediately in front of the window, was being overexposed to radiation. Shortly after the injection started, the mixer plugged. Solids built up in the mixer cove, but the cementer could not see what was happening. Instruments indicated that he was not getting enough solids to the jet, so he increased the flow of solids. The solids filled the mixer hopper and flowed through various vent lines and openings to the mixer tub and out into the mixer cell. This filled the cell to a height of about $3 \mathrm{ft}$ with contaminated solids and grout. The injection was shut down, and the solids in the mixer cell were washed down to the waste pit. From there they were pumped to the mixer tub and injected. Various pieces of equipment were washed or replaced, and the injection was resumed 3 days later. After about 3 hours, a leak was observed in the wellhead cell. A fitting had failed, and grout had been discharged into the cell and to the waste trench via the 18-in. line. The injection was halted, and the injection well was flushed and shut in. The wellhead cell was subsequently decontaminated; but in the process, sufficient grout was washed to the waste pit, mostly filling it. A cement cap was poured to fill the pit completely, and a new waste pit was constructed.

The facility was adapted for regular operational use in 1966 and was substantially upgraded at this time. Injections ILW-3 (November 1967) through ILW-7 (September 1970) were not well documented, and little is known except the volumes and curies injected.

Because the mixer tub was overfilled with water during washup operations following ILW-12 (January 24, 1975), several hundred gallons of waste were flushed to the waste pit.

During injection ILW-14 (June 18, 1975), the packing on one plunger of the injection pump failed, and grout flowed past the failed packing into the pump cell. After the injection was halted, the spilled grout was removed; and the pump cell was washed.

The erosion of a valve on the rack between the high pressure system and the drain to the waste pit was discovered during injection ILW-15 (June 30, 1977). This allowed grout to flow to the waste pit. The valve rack was bypassed temporarily, the leaked grout was pumped down the injection well, and the injection was ended. The eroded valves were subsequently replaced.

Also during injection IIW-15, the Moyno waste pumps overheated frequently. Because of trouble with the injection pump, the waste pumps were operated at an unusually low rate and were stopped and started frequently. This resulted in overheating of the pump motors and a tripping of the thermal overload switch. 
The injection pump diesel threw a connecting rod through the block during injection ILW-16 (November 17, 1977), ending the injection.

The last two injections at the facility were attempts to inject pelletized solids, both of which ultimately failed. In both operations, the pellets quickly plugged the well, which had to be back washed. Grout and pellets in the mixing tub and piping were discharged into the waste pit. 


\section{CURRENT SURVEILLANCE AND MAINTENANCE ACTIVITIES}

This section provides information on various investigative activities that have been conducted at the OHF Facility. These activities include sampling and analysis of the tank contents, radiation surveys, and various system operational and integrity tests.

\subsection{SAMPLING AND ANALYSIS}

A typical analysis of the waste stream pumped to the OHF Facility from two different waste storage tanks at the laboratory is shown in Table 5.1. Only liquid waste was pumped. The rate of transfer was between 20 and $25 \mathrm{gpm}$. Generally, a proportional sample for analysis was taken as the waste was transferred. On at least one occasion, however, grab samples from the tanks were analyzed; these samples generally showed higher concentrations of the insoluble components such as ${ }^{90} \mathrm{Sr}$ and transuranics (TRU).

The last tank sampling was performed in 1988 from an area adjacent to the manway. To minimize radiation exposure, only limited sample quantities were collected in the 1988 campaign providing only a general indication of the tank contents. The liquid was collected in $250-\mathrm{mL}$ jars, while the sludge samples were typically 10-20 g. All of the sludges were of a soft consistency so a noncutting collector tool could be used. Selected 1988 sampling results are given in Appendix B.

On the basis of the 1988 results, sludge in all the tanks can be classified as TRU waste, and both the liquid and the sludge are Resource Conservation and Recovery Act (RCRA) hazardous waste. Chromium, lead, and mercury in the waste exceed the RCRA limits. The pH of the supernate in tank T-3 also exceeded the RCRA characteristic criteria. These results are summarized in Table 5.2. Note that the RCRA determination was made on the basis of the use of the extraction procedure (EP)-toxicity equivalent test.

A new sampling campaign was initiated in December 1995 and will be completed in March 1996. The sampling and analysis plan includes criticality sampling and measurement of polychlorinated biphenyls in both the liquid and the sludge. In addition, several measurements are planned to comply with the waste acceptance criteria (WAC) for the Nevada Test Site and the MVSTs. Among these are $\mathrm{pH}$, conductivity, and viscosity and the density of suspended and dissolved solids. Also, the amounts of organics, and gross radiation scans were included to meet the WAC. Information from the 1988 results concerning radionuclides and heavy metals will be used to determine if WAC are met.

\subsection{RADIATION SURVEYS}

A preliminary radiation survey was conducted in September 1984 by the Environmental Occupation and Safety Division. This survey included both the interior of the buildings and the grounds. Building 7852 and the pump house were determined to be contaminated, as were the waste pits and the retention pond.

A walkover survey using USRADS was done in early 1992. This survey covered only the grounds and not the buildings or ponds. 
Table 5.1. Analysis of waste stream for injection $\mathrm{MW}-15$

\begin{tabular}{|c|c|c|}
\hline Component & W-8 & W-10 \\
\hline $\mathrm{NO}_{3}^{-} \mathrm{M}$ & 0.81 & 0.67 \\
\hline $\mathrm{NH}_{4}+, \mathrm{M}$ & 0.016 & 0.025 \\
\hline $\mathrm{Al}^{3}+, \mathrm{M}$ & 0.019 & 0.010 \\
\hline $\mathrm{Cr}^{3}+, \mathrm{M}$ & $3.8 \times 10^{-4}$ & $1.9 \times 10^{-4}$ \\
\hline $\mathrm{K}^{+}, \mathrm{M}$ & 0.261 & 0.120 \\
\hline $\mathrm{Na}^{+}, \mathrm{M}$ & 2.243 & 1.435 \\
\hline $\mathrm{CO}_{3}{ }^{2-}, \mathrm{M}$ & 0.45 & 0.33 \\
\hline $\mathrm{OH}^{\circ}, \mathrm{M}$ & 0.71 & 0.37 \\
\hline $\mathrm{Cl}^{-}, \mathrm{M}$ & 0.172 & 0.162 \\
\hline $\mathrm{SO}_{4}^{2-}, \mathrm{M}$ & 0.102 & 0.113 \\
\hline Specific gravity & 1.184 & 1.123 \\
\hline $\mathrm{Cr} \mathrm{mg} / \mathrm{mL}$ & 0.02 & 0.01 \\
\hline $\mathrm{Cu}$ & SNF & SNF \\
\hline $\mathrm{Fe}$ & $<0.005$ & $<0.005$ \\
\hline $\mathrm{Ni}$ & SNF & SNF \\
\hline $\mathrm{Pb}$ & SNF & SNF \\
\hline $\mathrm{Sb}$ & SNF & SNF \\
\hline $\mathrm{Si}$ & SNF & SNF \\
\hline Sn & SNF & $\mathrm{SNF}$ \\
\hline $\mathrm{Ti}$ & SNF & SNF \\
\hline V & SNF & SNF \\
\hline $\mathrm{Zr}$ & SNF & SNF \\
\hline${ }^{137} \mathrm{Cs}, \mathrm{Ci} / \mathrm{L}$ & NA & $7.7 \times 10^{-2}$ \\
\hline${ }^{90} \mathrm{Sr}, \mathrm{Ci} / \mathrm{L}$ & NA & $1.5 \times 10^{-4}$ \\
\hline${ }^{60} \mathrm{Co}, \mathrm{Ci} / \mathrm{L}$ & NA & $8.5 \times 10^{-4}$ \\
\hline${ }^{106} \mathrm{Ru}, \mathrm{Ci} / \mathrm{L}$ & NA & $7.3 \times 10^{-4}$ \\
\hline${ }^{238} \mathrm{Pu}, \mathrm{Ci} / \mathrm{L}$ & NA & $1.2 \times 10^{-6}$ \\
\hline${ }^{239} \mathrm{Pu}, \mathrm{Ci} / \mathrm{L}$ & NA & None \\
\hline
\end{tabular}


Table 5.2. RCRA characterization from 1988 analysis

\begin{tabular}{c|cc|cccc}
\hline & RCRA Waste Status & \multicolumn{3}{|c|}{ Liquid } & Sludge \\
\cline { 2 - 7 } Tank & Liquid & Sludge & Corrosive? & $\begin{array}{c}\text { Hazardous metals } \\
\text { above regulatory limit } \\
\text { (mg/L) }\end{array}$ & $\begin{array}{c}\text { Hazardous metals above } \\
\text { EP-toxicity equivalent } \\
\text { (mg/kg) }\end{array}$ \\
\hline T1 & Non-RCRA & RCRA & No & None & $\mathrm{Cr}(130), \mathrm{Hg}(74), \mathrm{Pb}(860)$ \\
T2 & Non-RCRA & RCRA & No & None & $\mathrm{Cr}(180), \mathrm{Hg}(70), \mathrm{Pb}(350)$ \\
T3 & RCRA & RCRA & Yes (pH=12.7) & $\mathrm{Cr}(14), \mathrm{Hg}(5.7)$ & $\mathrm{Hg}(40), \mathrm{Pb}(300)$ \\
T4 & RCRA & RCRA & No & $\mathrm{Cr}(14), \mathrm{Hg}(7.9)$ & $\mathrm{Cr}(102), \mathrm{Hg}(585), \mathrm{Pb}(510)$ \\
T9 & RCRA & RCRA & No & $\mathrm{Hg}(3.4)$ & $\mathrm{Hg}(39), \mathrm{Pb}(540)$ \\
\hline
\end{tabular}

A survey of the valve pit was performed on July 15,1993 . This survey showed the valve pit to be highly contaminated with a beta-emitter, believed to be ${ }^{90} \mathrm{Sr}$.

The 1984 survey also included soil samples. These samples did not show migration from the tanks, pit or pond. In late 1993, soil samples were taken at several OHF Facility locations. These locations included known spill spots and areas with elevated radioactivity levels identified by the USRADS survey. However, the source of the soil contamination may not be the OHF Facility. WAG 5, a large waste burial ground, is upgradient of the OHF Facility and could be the source of this contamination.

In 1994, Building 7852, the storage bins, pump house, water tank, and Pump P-3 were characterized (Bechtel 1995). Radiological and chemical testing of soil, water, grout, and concrete was performed for these areas. The exteriors of the storage bins, water tank and Pump P-3 were found to be free of contamination. The control room and engine pad were found to have low levels of contamination except for a few isolated locations. Higher levels were found in the cells and pump house. Most of the contamination was fixed, with the exception of loose grout in the mixing cell and piping. The major contaminant was found to $b e^{137} \mathrm{Cs} /{ }^{137 m} \mathrm{Ba}$. Present in smaller amounts were ${ }^{90} \mathrm{Sr} /{ }^{90} \mathrm{Y}$ and some alpha emitters.

\subsection{SYSTEM OPERATIONAL AND INTEGRITY TESTS}

\subsubsection{Tank Level}

The level inside each tank and the condition of the dry wells associated with the tanks are monitored monthly. Although the readings show some fluctuations, they can be explained by gauge parallax, temperature effects, and the like. Long-term trends of both indicators show no indication of leakage of the tank contents.

Generally, no liquid is detected at the bottom of the dry well, except accumulated precipitation, which is periodically sampled. When visual inspection reveals liquid in the well, a grab sample is collected. Historically, these samples have shown minimal contamination, usually less than $2.7 \times 10^{-8} \mathrm{Ci} / \mathrm{L}$ (gross beta). No samples have exceeded $2.7 \times 10^{-7} \mathrm{Ci} / \mathrm{L}$. As with the previously discused soil contamination, the potential is that the contamination is from seepage from the burial grounds rather than from the tanks. 


\section{5-4}

\subsubsection{Integrity Tests}

Pressure Tests on Piping. A pressure test on the line from the south tank farm to the valve pit was conducted on July 14,1993 . The section of line tested included all the line from the liquid low-level waste evaporator to the valve box at the OHF Facility. This section included the new tie-in and the old carbon steel line to the valve box at the OHF control area, but not the manifold in the valve pit. The line held at 150 psi for 23 hours and indicated no leakage in the line.

Tank Integrity. Recently, a corrosion study was done on carbon steel tanks at Savannah River. This report indicates that corrosion will be minimal as long as the tanks are kept basic with at least $0.1 \mathrm{M}$ sodium hydroxide with some nitrate. During operation of the OHF Facility, the solution was kept basic. The latest tank samples indicate that the material now in the tanks also has a high $\mathrm{pH}$. These results suggest that internal corrosion will not be a problem.

Because the tanks have been buried underground for more than 35 years, tank integrity and the potential for corrosion and tank wall failure are concerns. Cathodic protection was provided to the tanks in 1968 to prevent external corrosion. However, the design used a sacrificial anode, which expired in the early 1990s. An analysis was done to estimate replacement costs, and a decision was made not to replace the anodes. It is not certain that replacing the anodes would have had a positive effect. All tanks are now without cathodic protection. 


\section{REFERENCES}

Bechtel National, Inc. 1995. Site Characterization Report for the Old Hydrofracture Facility at Oak Ridge National Laboratory, Oak Ridge, Tennessee. ORNL/ER/Sub/87-99053/75. Oak Ridge National Laboratory, Oak Ridge, Tennessee

DOE (Department of Energy). 1995. Remedial Investigation Report on Waste Area Grouping 5 at Oak Ridge National Laboratory, Oak Ridge, Tennessee. DOE/OR/01-1326\&D1/V1-V3. ORNL/ER284\&D1/V1. ORNL/ER/Sub/87-99053/76/V1. Oak Ridge National Laboratory, Oak Ridge, Tennessee.

Francis, C.W., and R.G. Stansfield. 1986. Characterization Plan for the Old Hydrofracture Facility. ORNL/TM-9991. Oak Ridge National Laboratory, Oak Ridge, Tennessee.

Weeren, H.O. 1974. Shale Fracturing Injections at ORNL - 1972 Series. ORNL/TM-4467. Oak Ridge National Laboratory, Oak Ridge, Tennessee.

Weeren, H.O. 1976. Shale Fracturing Injections at ORNL - 1975 Series. ORNL/TM-5545. Oak Ridge National Laboratory, Oak Ridge, Tennessee.

Weeren, H.O. 1980. Shale Fracturing Injections at ORNL - 1977-1979 Series. ORNL/TM-7421. Oak Ridge National Laboratory, Oak Ridge, Tennessee. 
APPENDIX A

\section{SUMMARY OF TANK INFORMATION}




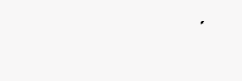


TANK T-1

1. SITE NAME: Tank T-1

2. LOCATION: Old Hydrofracture Facility, west of Building 7852

3. SERVICE DATES: 1963-1980

4. HISTORY: Tank T-1 was a storage tank for ILW before injection into hydrofracture wells. The tank is located under $4 \mathrm{ft}$ of compacted earth with $5.5 \mathrm{ft}$ of 1 -in. gravel backfill around the tank. It is accessed through an 18-in. manhole.

5. CURRENT STATUS: Based on the tank volume measured in September 1995 and the sludge volume measured in the 1988 sampling campaign, the tank contains 11,047 gal of liquid and 791 gal of sludge.

\section{DESCRIPTION:}

A. Tank. Tank T-1 is a 15,000-gal, mild steel tank.

B. Instrumentation. LE-T1, pneumatic level monitoring

C. Contents. 1988 sampling results: (liquids) $2.1 \mathrm{E}+02 \mathrm{~Bq} / \mathrm{mL}$ gross alpha; $8.1 \mathrm{E}+04 \mathrm{~Bq} / \mathrm{mL}$ gross beta and (sludges) $6.5 \mathrm{E}+05 \mathrm{~Bq} / \mathrm{g}$ gross alpha; $5.9 \mathrm{E}+07 \mathrm{~Bq} / \mathrm{g}$ gross beta.

7. SURVEILLANCE AND MAINTENANCE ACTIVITIES:

Table A-1. Tank T-1 surveillance and maintenance activities

\begin{tabular}{llll}
\hline \multicolumn{1}{c}{ Activity } & Frequency & Responsibility & \multicolumn{1}{c}{ Documentation } \\
\hline 1. Site inspection & Weekly & FM & See note \\
2. Waste tank level monitoring & Daily & FM & $\begin{array}{l}\text { TANK database and letter } \\
\text { to intermediate liquid low- } \\
\text { level waste tank manager }\end{array}$ \\
3. Sample dry well & Monthly & FM & Waste Operations \\
4. Check filter system & Weekly & FM & Waste Operations \\
\hline
\end{tabular}

Note: Site inspection is to be documented on an as-needed basis.

FM= facility manager 


\section{TANK T-2}

1. SITE NAME: Tank T-2

2. LOCATION: Old Hydrofracture Facility, west of Building 7852

3. SERVICE DATES: $1963-1980$

4. HISTORY: Tank T-2 was a storage tank for ILW before injection into hydrofracture wells. The tank is located under $4 \mathrm{ft}$ of compacted earth with $5.5 \mathrm{ft}$ of 1 -in. gravel backfill around the tank. It is accessed through an 18-in. manhole.

5. CURRENT STATUS: Based on the tank volume measured in September 1995 and the sludge volume measured in the 1988 sampling campaign, the tank contains 11,048 gal of liquid and 1205 gal of sludge.

6. DESCRIPTION:

A. Tank. Tank T-2 is a 15,000-gal, mild steel tank.

B. Instrumentation. LE-T2, pneumatic level monitoring

C. Contents. 1988 sampling results: (liquids) $2.1 \mathrm{E}+02 \mathrm{~Bq} / \mathrm{mL}$ gross alpha; $1.4 \mathrm{E}+05 \mathrm{~Bq} / \mathrm{mL}$ gross beta and (sludges) $2.5 \mathrm{E}+05 \mathrm{~Bq} / \mathrm{g}$ gross alpha; $2.0 \mathrm{E}+07 \mathrm{~Bq} / \mathrm{g}$ gross beta.

\section{SURVEILLANCE AND MAINTENANCE ACTIVITIES:}

Table A-2. Tank T-2 surveillance and maintenance activities

\begin{tabular}{llll}
\hline Activity & Frequency & Responsibility & Documentation \\
\hline 1. Site inspection & Weekly & FM & See Note \\
2. Waste tank level monitoring & Daily & FM & $\begin{array}{l}\text { TANK database and letter to } \\
\text { intermediate liquid low-level } \\
\text { waste tank mnager }\end{array}$ \\
3. Sample dry well & Monthly & FM & Waste Operations \\
4. Check filter system & Weekly & FM & Waste Operations \\
\hline
\end{tabular}

Note: Site inspection is to be documented on an as-needed basis.

FM $=$ facility manager 


\section{TANK T-3}

1. SITE NAME: Tank T-3

2. LOCATION: Old Hydrofracture Facility, west of Building 7852

3. SERVICE DATES: $1966-1980$

4. HISTORY: Tank T-3 was a storage tank for ILW before injection into hydrofracture wells. The tank is located under $4 \mathrm{ft}$ of compacted earth with $5.9 \mathrm{ft}$ of crushed stone backfill around the tank. It is accessed through an 18-in. manway.

5. CURRENT STATUS: Based on the tank volume measured in September 1995 and the sludge volume measured in the 1988 sampling campaign, the tank contains 2063 gal of liquid and $2029 \mathrm{gal}$ of sludge.

\section{DESCRIPTION:}

A. Tank. Tank T-3 is a 25,000-gal, carbon steel tank that is rubber lined.

B. Instrumentation. LE-T3, pneumatic level monitoring

C. Contents. 1988 sampling results: (liquids) $2.0 \mathrm{E}+00 \mathrm{~Bq} / \mathrm{mL}$ gross alpha; $2.8 \mathrm{E}+05 \mathrm{~Bq} / \mathrm{mL}$ gross beta and (sludges) $2.0 \mathrm{E}+05 \mathrm{~Bq} / \mathrm{g}$ gross alpha; $2.5 \mathrm{E}+07 \mathrm{~Bq} / \mathrm{g}$ gross beta.

7. SURVEILLANCE AND MAINTENANCE ACTIVITIES:

Table A-3. Tank T-3 surveillance and maintenance activities

\begin{tabular}{llll}
\hline Activity & Frequency & Responsibility & Documentation \\
\hline 1. Site inspection & Weekly & FM & See Note \\
2. Waste tank level monitoring & Daily & FM & $\begin{array}{l}\text { TANK databaseand letter to } \\
\text { intermediate liquid low-level } \\
\text { waste tank manager }\end{array}$ \\
3. Sample dry well & Monthly & FM & Waste Operations \\
4. Check filter system & Weekly & FM & Waste Operations \\
\hline
\end{tabular}

Note: Site inspection is to be determined on an as-needed basis.

$\mathrm{FM}=$ facility manager 


\section{TANK T-4}

1. SITE NAME: Tank T-4

2. LOCATION: Old Hydrofracture Facility, west of Building 7852

3. SERVICE DATES: $1966-1980$

4. HISTORY: Tank T-4 was a storage tank for ILW before injection into hydrofracture wells. The tank is located under $4 \mathrm{ft}$ of compacted earth with $5.9 \mathrm{ft}$ of crushed stone backfill around the tank. It is accessed through an 18-in. manway.

5. CURRENT STATUS: Based on the tank volume measured in September 1995 and the sludge volume measured in the 1988 sampling campaign, the tank contains 9341 gal of liquid and 1328 gal of sludge.

6. DESCRIPTION:

A. Tank. Tank T-4 is a 25,000-gal, carbon steel tank that is rubber lined.

B. Instrumentation. LE-T4, pneumatic level monitoring

C. Contents. sampling results: (liquids) $4.9 \mathrm{E}+01 \mathrm{~Bq} / \mathrm{mL}$ gross alpha; $3.1 \mathrm{E}+05 \mathrm{~Bq} / \mathrm{mL}$ gross beta and (sludges) $3.7 \mathrm{E}+05 \mathrm{~Bq} / \mathrm{g}$ gross alpha; $3.6 \mathrm{E}+07 \mathrm{~Bq} / \mathrm{g}$ gross beta.

\section{SURVEILLANCE AND MAINTENANCE ACTIVITIES:}

Table A-4. Tank $\mathbf{T}-4$ surveillance and maintenance activities

\begin{tabular}{llll}
\hline Activity & Frequency & Responsibility & Documentation \\
\hline 1. Site inspection & Weekly & FM & See Note \\
2. Waste tank level monitoring & Daily & FM & $\begin{array}{l}\text { TANK database and letter to } \\
\text { intermediate liquid low-level } \\
\text { waste tank manager }\end{array}$ \\
3. Sample dry well & Monthly & FM & Waste Operations \\
4. Check filter system & Weekly & FM & Waste Operations \\
\hline
\end{tabular}

Note: Site inspection is to be documented on an as-needed basis.

$\mathrm{FM}=$ facility manager 


\section{TANK T-9}

1. SITE NAME: Tank T-9

2. LOCATION: Old Hydrofracture Facility, west of Building 7852

3. SERVICE DATES: $1963-1980$

4. HISTORY: Tank T-9 was a storage tank for LLLW prior to injection into hydrofracture wells. The tank is located under $4 \mathrm{ft}$ of compacted earth with $5.5 \mathrm{ft}$ of 1 -in. gravel backfill around the tank. It is accessed through an 18-in. manhole.

5. CURRENT STATUS: Based on the tank volume measured in September 1995 and the sludge volume measured in the 1988 sampling campaign, the tank contains 1290 gal of liquid and 481 gal of sludge.

\section{DESCRIPTION:}

A. Tank. Tank T-9 is a 13,000-gal, mild steel tank.

B. Instrumentation. LE-T9, pneumatic level monitoring

C. Contents. 1988 sampling results: (liquids) $7.0 \mathrm{E}+02 \mathrm{~Bq} / \mathrm{mL}$ gross alpha; $3.4 \mathrm{E}+05 \mathrm{~Bq} / \mathrm{mL}$ gross beta and (sludges) $1.5 \mathrm{E}+05 \mathrm{~Bq} / \mathrm{g}$ gross alpha; $1.6 \mathrm{E}+07 \mathrm{~Bq} / \mathrm{g}$ gross beta.

\section{SURVEILLANCE AND MAINTENANCE ACTIVITIES:}

Table A-5. Tank T-9 surveillance and maintenance activities

\begin{tabular}{llll}
\hline Activity & Frequency & Responsibility & Documentation \\
\hline 1. Site inspection & Weekly & FM & See Note \\
2. Waste tank level monitoring & Daily & FM & $\begin{array}{l}\text { TANK database \& letter to } \\
\text { intermediate liquid low-level } \\
\text { waste tank manager }\end{array}$ \\
3. Sample dry well & Monthly & FM & Waste Operations \\
4. Check filter system & Weekly & FM & Waste Operations \\
\hline
\end{tabular}

Note: Site inspection is to be documented on an as-needed basis.

$\mathrm{FM}=$ facility manager 
APPENDIX B

SELECTED SAMPLING RESULTS FROM 1988 


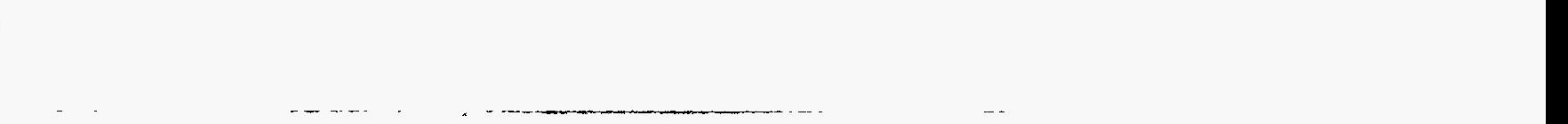




\section{B-3}

Table B-1. Tank T-1 sampling results from 1988

\begin{tabular}{|c|c|c|c|}
\hline Substance & $\mathbf{L 3 5}$ & $\mathbf{L 3 6}$ & S37 \\
\hline \multicolumn{4}{|c|}{$R C R A$ metals $(L=m g / L, S=m g / k g)$} \\
\hline $\mathrm{Ag}$ & 0.01 & 0.005 & 2.1 \\
\hline As & $<0.8$ & $<0.8$ & $<2$ \\
\hline $\mathrm{Ba}$ & $<0.04$ & 0.05 & 88 \\
\hline $\mathrm{Cd}$ & $<0.02$ & $<0.02$ & 12.9 \\
\hline $\mathrm{Cr}$ & 0.29 & 0.18 & $(130)$ \\
\hline $\mathrm{Hg}$ & 0.06 & 0.07 & 74 \\
\hline $\mathrm{Ni}$ & $<0.2$ & $<0.2$ & 190 \\
\hline $\mathrm{Pb}$ & $<1$ & $<1$ & $(860)$ \\
\hline $\mathrm{Se}$ & $<0.2$ & $<0.2$ & $(<2)$ \\
\hline $\mathrm{Tl}$ & $<0.2$ & $<0.2$ & 1.7 \\
\hline \multicolumn{4}{|c|}{ Process metals $(L=m g / L, S=m g / k g)$} \\
\hline $\mathrm{Si}$ & 9.34 & 6.81 & NA \\
\hline $\mathrm{U}$ & 172 & 175 & 2800 \\
\hline \multicolumn{4}{|c|}{ Beta/gamma emitters $(L=B q / m L, S=B q / g)$} \\
\hline${ }^{137} \mathrm{Cs}$ & $7.4 \times 10^{4}$ & $7.5 \times 10^{4}$ & $3.9 \times 10^{5}$ \\
\hline${ }^{14} \mathrm{C}$ & * & $*$ & 48 \\
\hline${ }^{132} \mathrm{Eu}$ & * & * & $1.4 \times 10^{5}$ \\
\hline${ }^{154} \mathrm{Eu}$ & * & * & $1.2 \times 10^{5}$ \\
\hline${ }^{155} \mathrm{Eu}$ & * & * & $2.3 \times 10^{4}$ \\
\hline${ }^{3} \mathrm{H}$ & 71 & 71 & 26 \\
\hline${ }^{60} \mathrm{Co}$ & $<50$ & $<50$ & $2.6 \times 10^{5}$ \\
\hline${ }^{90} \mathrm{Sr}$ & $3.3 \times 10^{3}$ & $3.4 \times 10^{3}$ & $3.2 \times 10^{7}$ \\
\hline \multicolumn{4}{|c|}{ Alpha emitters $(\mathrm{L}=\mathrm{Bq} / \mathrm{mL}, \mathrm{S}=\mathrm{Bq} / \mathrm{g})$} \\
\hline${ }^{233} \mathrm{U}$ & 180 & 200 & * \\
\hline${ }^{238} \mathrm{Pu}$ & * & * & $3.4 \times 10^{4}$ \\
\hline${ }^{239} \mathrm{Pu}$ & $*$ & * & $6.5 \times 10^{3}$ \\
\hline
\end{tabular}


Table B-2. Tank T-2 sampling results from 1988

\begin{tabular}{|c|c|c|c|c|}
\hline Substance & $\mathbf{L 3 8}$ & L39 & L112 & S40 \\
\hline \multicolumn{5}{|c|}{$R C R A$ metals $(L=m g / L, S=m g / k g)$} \\
\hline $\mathrm{Ag}$ & $<0.002$ & 0.002 & $<0.002$ & 2.9 \\
\hline As & $<0.8$ & $<0.8$ & $<0.8$ & $<1$ \\
\hline $\mathrm{Ba}$ & $<0.04$ & $<0.04$ & 0.06 & 33 \\
\hline Cd & $<0.02$ & $<0.02$ & $<0.02$ & 6.6 \\
\hline $\mathrm{Cr}$ & 0.44 & $<0.1$ & $<0.1$ & $(180)$ \\
\hline $\mathrm{Hg}$ & 0.1 & 0.15 & 0.1 & 70 \\
\hline $\mathrm{Ni}$ & $<0.2$ & $<0.2$ & $<0.2$ & 72 \\
\hline $\mathrm{Pb}$ & $<1$ & $<1$ & $<1$ & $(350)$ \\
\hline $\mathrm{Se}$ & $<0.09$ & $<0.09$ & $<0.09$ & $(<1)$ \\
\hline $\mathrm{Tl}$ & $<0.09$ & $<0.09$ & $<0.09$ & $<1$ \\
\hline \multicolumn{5}{|c|}{ Process metals $(L=m g / L, S=m g / k g)$} \\
\hline $\mathrm{Si}$ & 5.07 & 6.97 & 6.81 & NA \\
\hline $\mathrm{U}$ & 166 & 158 & 161 & 1000 \\
\hline \multicolumn{5}{|c|}{ Beta/gamma emitters $(L=B q / m L, S=B q / g)$} \\
\hline${ }^{137} \mathrm{Cs}$ & $1.4 \times 10^{5}$ & $1.4 \times 10^{5}$ & $1.4 \times 10^{5}$ & $2.5 \times 10^{5}$ \\
\hline${ }^{14} \mathrm{C}$ & 480 & 230 & 360 & 17 \\
\hline${ }^{152} \mathrm{Eu}$ & * & * & * & $3.8 \times 10^{4}$ \\
\hline${ }^{154} \mathrm{Eu}$ & * & * & * & $2.6 \times 10^{4}$ \\
\hline${ }^{15 s} \mathrm{Eu}$ & * & * & * & $3.8 \times 10^{3}$ \\
\hline${ }^{3} \mathrm{H}$ & 210 & 210 & 210 & 95 \\
\hline${ }^{60} \mathrm{Co}$ & $<75$ & $<75$ & $<75$ & $6.4 \times 10^{4}$ \\
\hline${ }^{90} \mathrm{Sr}$ & $2.5 \times 10^{3}$ & $2.7 \times 10^{3}$ & $2.8 \times 10^{3}$ & $1.2 \times 10^{7}$ \\
\hline \multicolumn{5}{|c|}{ Alpha emitters $(L=B q / m L, S=B q / g)$} \\
\hline${ }^{233} \mathrm{U}$ & 190 & 180 & 180 & $8.3 \times 10^{3}$ \\
\hline${ }^{238} \mathrm{Pu}$ & * & * & $*$ & $3.1 \times 10^{3}$ \\
\hline${ }^{239} \mathrm{Pu}$ & $*$ & $*$ & * & $5.1 \times 10^{3}$ \\
\hline${ }^{24} \mathrm{Cm}$ & $*$ & $*$ & $*$ & $<200$ \\
\hline${ }^{252} \mathrm{Cf}$ & & $*$ & $*$ & $1.8 \times 10^{5}$ \\
\hline
\end{tabular}

() - suspect data, *- data not available, NA- data not applicable 
B-5

Table B-3. Tank T-3 sampling results from 1988

\begin{tabular}{|c|c|c|}
\hline Substance & $\mathbf{L 4 2}$ & $\mathbf{S 4 3}$ \\
\hline \multicolumn{3}{|c|}{$R C R A$ metals $(L=m g / L, S=m g / k g)$} \\
\hline Ag & $<0.01$ & 0.15 \\
\hline As & 0.4 & $<3$ \\
\hline $\mathrm{Ba}$ & $\varangle 0.02$ & 76 \\
\hline Cd & $<0.01$ & 8.5 \\
\hline $\mathrm{Cr}$ & 14 & (69) \\
\hline $\mathrm{Hg}$ & 5.7 & 40 \\
\hline $\mathrm{Ni}$ & $<0.1$ & 57 \\
\hline $\mathrm{Pb}$ & $<0.5$ & $(300)$ \\
\hline $\mathrm{Se}$ & $<0.5$ & $(0.74)$ \\
\hline $\mathrm{Tl}$ & $<0.5$ & $<0.6$ \\
\hline \multicolumn{3}{|c|}{ Process metals $(L=m g / L, S=m g / k g)$} \\
\hline $\mathrm{Si}$ & 77.1 & NA \\
\hline $\mathrm{U}$ & 0.2 & 3060 \\
\hline \multicolumn{3}{|c|}{ Beta/gamma emitters $(L=B q / m L, S=B q / g)$} \\
\hline${ }^{137} \mathrm{Cs}$ & $2.7 \times 10^{5}$ & $1.3 \times 10^{6}$ \\
\hline${ }^{14} \mathrm{C}$ & * & 760 \\
\hline${ }^{152} \mathrm{Eu}$ & $*$ & $5.1 \times 10^{4}$ \\
\hline${ }^{154} \mathrm{Eu}$ & $*$ & $5.3 \times 10^{4}$ \\
\hline${ }^{3} \mathrm{H}$ & 170 & 77 \\
\hline${ }^{60} \mathrm{Co}$ & 360 & $1.6 \times 10^{5}$ \\
\hline${ }^{90} \mathrm{Sr}$ & 300 & $8.1 \times 10^{6}$ \\
\hline \multicolumn{3}{|c|}{ Alpha emitters $(L=B q / m L, S=B q / g)$} \\
\hline${ }^{233} \mathrm{U}$ & 2.0 & $8.3 \times 10^{3}$ \\
\hline${ }^{238} \mathrm{Pu}$ & * & $1.4 \times 10^{4}$ \\
\hline${ }^{239} \mathrm{Pu}$ & * & $5.3 \times 10^{3}$ \\
\hline${ }^{244} \mathrm{Cm}$ & * & $1.8 \times 10^{5}$ \\
\hline${ }^{252} \mathrm{Cf}$ & * & $<200$ \\
\hline
\end{tabular}




\section{B-6}

Table B-4. Tank T-4 sampling results from 1988

\begin{tabular}{|c|c|c|c|c|}
\hline Substance & L44 & $\mathrm{L} 45$ & L111 & S46 \\
\hline \multicolumn{5}{|c|}{$R C R A$ metals $(L=m g / L, S=m g / k g)$} \\
\hline $\mathrm{Ag}$ & 0.017 & 0.02 & 0.018 & (1.7) \\
\hline As & $<0.8$ & $<0.8$ & $<0.4$ & $<4$ \\
\hline $\mathrm{Ba}$ & $<0.04$ & $<0.04$ & $<0.02$ & $<50$ \\
\hline $\mathrm{Cd}$ & $<0.02$ & $<0.02$ & $<0.01$ & 10 \\
\hline $\mathrm{Cr}$ & 9.4 & 14 & 13 & $(102)$ \\
\hline $\mathrm{Hg}$ & 1.1 & 2.7 & 7.9 & 585 \\
\hline $\mathrm{Ni}$ & $<0.2$ & $<0.2$ & $<0.1$ & 160 \\
\hline $\mathrm{Pb}$ & $<1$ & $<1$ & $<0.5$ & $(510)$ \\
\hline Se & $<0.09$ & $<0.09$ & $<0.23$ & (1.5) \\
\hline $\mathrm{Tl}$ & $<0.09$ & $<0.09$ & $<0.23$ & 0.73 \\
\hline \multicolumn{5}{|c|}{ Process metals $(L=m g / L, S=m g / k g)$} \\
\hline $\mathrm{Si}$ & 1.96 & 1.45 & 1.96 & $\mathrm{NA}$ \\
\hline $\mathrm{U}$ & 25.7 & 27.8 & 23.3 & 1850 \\
\hline \multicolumn{5}{|c|}{ Beta/gamma emitters $(L=B q / m L, S=B q / g)$} \\
\hline${ }^{137} \mathrm{Cs}$ & $3.0 \times 10^{5}$ & $3.0 \times 10^{5}$ & $3.0 \times 10^{5}$ & $4.5 \times 10^{5}$ \\
\hline${ }^{14} \mathrm{C}$ & * & * & * & 510 \\
\hline${ }^{152} \mathrm{Eu}$ & * & * & * & $5.2 \times 10^{4}$ \\
\hline${ }^{154} \mathrm{Eu}$ & * & * & * & $4.4 \times 10^{4}$ \\
\hline${ }^{155} \mathrm{Eu}$ & * & * & * & $7.0 \times 10^{3}$ \\
\hline${ }^{3} \mathrm{H}$ & 110 & 110 & 110 & 28 \\
\hline${ }^{60} \mathrm{Co}$ & 64 & 52 & 52 & $6.0 \times 10^{4}$ \\
\hline${ }^{90} \mathrm{Sr}$ & $1.2 \times 10^{3}$ & $1.4 \times 10^{3}$ & $1.4 \times 10^{3}$ & $2.2 \times 10^{7}$ \\
\hline \multicolumn{5}{|c|}{ Alpha emitters $(L=B g / m L, S=B q / g)$} \\
\hline${ }^{233} \mathrm{U}$ & 22 & 29 & 23 & $7.1 \times 10^{3}$ \\
\hline${ }^{238} \mathrm{Pu}$ & $*$ & * & * & $2.2 \times 10^{4}$ \\
\hline${ }^{238} \mathrm{Th} /{ }^{232} \mathrm{Th}$ & * & $*$ & $*$ & 580 \\
\hline${ }^{239} \mathrm{Pu}$ & $*$ & $*$ & $*$ & $4.6 \times 10^{3}$ \\
\hline${ }^{241} \mathrm{Am}$ & * & $*$ & * & $8.2 \times 10^{3}$ \\
\hline${ }^{24} \mathrm{Cm}$ & $*$ & * & * & $2.1 \times 10^{5}$ \\
\hline
\end{tabular}


B-7

Table B-5. Tank T-9 sampling results from 1988

\begin{tabular}{|c|c|c|}
\hline Substance & LA7 & $\mathbf{S} 4$ \\
\hline \multicolumn{3}{|c|}{$R C R A$ metals $(L=m g / L, S=m g / k g$} \\
\hline $\mathrm{Ag}$ & 0.01 & \\
\hline As & $<0.8$ & \\
\hline $\mathrm{Ba}$ & 0.12 & \\
\hline Cd & $<0.02$ & \\
\hline $\mathrm{Cr}$ & 0.4 & \\
\hline $\mathrm{Hg}$ & 3.4 & \\
\hline $\mathrm{Ni}$ & $\infty .2$ & \\
\hline $\mathrm{Pb}$ & $<1$ & \\
\hline $\mathrm{Se}$ & $<0.09$ & \\
\hline $\mathrm{Tl}$ & $<0.09$ & \\
\hline
\end{tabular}

Process metals $(L=m g / L, S=m g / k g)$

$\begin{array}{ccc}\mathrm{Si} & 9.76 & \text { NA } \\ \mathrm{U} & 852 & 2930\end{array}$

Betalgamma emitters $(L=B q / m L, S=B q / g)$

${ }^{137} \mathrm{Cs} \quad 2.9 \times 10^{5} \quad 4.0 \times 10^{5}$

${ }^{14} \mathrm{C} \quad 2.2 \times 10^{3}$

${ }^{152} \mathrm{Eu} \quad * \quad 3.5 \times 10^{4}$

${ }^{154} \mathrm{Eu} \quad * \quad 8.9 \times 10^{3}$

$\begin{array}{lll}{ }^{3} \mathrm{H} & 160 & 34\end{array}$

${ }^{60} \mathrm{Co} \quad 6.0 \times 10^{3} \quad 4.3 \times 10^{4}$

${ }^{90} \mathrm{Sr} \quad 3.6 \times 10^{4} \quad 1.4 \times 10^{7}$

Alpha emitters $(L=B q / m L, S=B q / g)$

${ }^{233} \mathrm{U} \quad 660 \quad 4.4 \times 10^{3}$

${ }^{238} \mathrm{Pu} \quad * \quad 1.0 \times 10^{4}$

${ }^{239} \mathrm{Pu} \quad * \quad 4.3 \times 10^{3}$

${ }^{24} \mathrm{Cm} \quad * \quad 9.7 \times 10^{4}$

${ }^{252} \mathrm{Cf} \quad * \quad<2$

() - suspect data, *- data not available, NA- data not applicable 


\section{DISTRIBUTION}

1. L. V. Asplund

2. C. A. Bednarz

3. H. L. Boston

4. W. D. Brickeen

5. D. G. Cope

6. D. L. Garrett

7. T. B. Hale

8. A. J. Kuhaida, Jr.

9. D. M. Matteo

10. K. A. McPherson

11-12. P. T. Owen

13. S. T. Rudell

14. P. A. Schrandt

15. C. B. Scott

16. A. E. Smith

17. W. T. Thompson

18. M. L. Whitehead

19. Central Research Library

20. ER Document Management Center-RC

21. C. L. Callis, CDM Federal Programs Corporation, 800 Oak Ridge Turnpike, Suite 500, Oak Ridge, Tennessee 37830

22. C. Provost, CDM Federal Programs Corporation, 800 Oak Ridge Turnpike, Suite 500, Oak Ridge, Tennessee 37830

23. R. Casteele, Parallax, Inc., 95 Main Street West, Second Floor, Oak Ridge, Tennessee 37830

24. P. H. Clarke, Parallax, Inc., 95 Main Street West, Second Floor, Oak Ridge, Tennessee 37830

25. M. D. Jackson, Parallax, Inc., 95 Main Street West, Second Floor, Oak Ridge, Tennessee 37830

26. B. A. Wilson, Parallax, Inc., 95 Main Street West, Second Floor, Oak Ridge, Tennessee 37830

27-28. Office of Scientific and Technical Information, P.O. Box 62, Oak Ridge, Tennessee 37831 